Metallurgical and Materials Transactions A, 2000, Vol. 31A, No. 10, pp. 2491-2502.

\title{
MODELING CREEP AND FATIGUE OF COPPER ALLOYS
}

\author{
G. Li, ${ }^{1}$ B. G. Thomas, ${ }^{2}$ and J. F. Stubbins ${ }^{3}$
}

\begin{abstract}
This paper reviews expressions to quantify thermal creep and fatigue lifetime for four copper alloys, $\mathrm{Cu}-\mathrm{Ag}-\mathrm{P}, \mathrm{Cu}-\mathrm{Cr}-\mathrm{Zr}, \mathrm{Cu}-\mathrm{Ni}-\mathrm{Be}$ and $\mathrm{Cu}-\mathrm{Al}_{2} \mathrm{O}_{3}$. These property models are needed to simulate the mechanical behavior of structures with copper components that are subjected to high heat flux and fatigue loading conditions, such as molds for the continuous casting of steel and the first wall in a fusion reactor. Then, measurements of four-point bending fatigue tests were conducted on two-layered specimens of copper alloy and stainless steel, and thermal ratchetting behavior was observed at $250{ }^{\circ} \mathrm{C}$. The test specimens were modeled with a two-dimensional elastic-plastic-creep finite-element model using ABAQUS. To match the measurements, a primary thermal creep law was developed for $\mathrm{Cu}-0.28 \% \quad \mathrm{Al}_{2} \mathrm{O}_{3}$ for stress levels up to $500 \mathrm{MPa}$, and strain rates from $10^{-8}-10^{-2} \mathrm{~s}^{-1}$. Specifically,

$\dot{\varepsilon}\left(\mathrm{s}^{-1}\right)=1.43 \times 10^{10} \exp \left(-\frac{197000}{8.31 \mathrm{~T}(\mathrm{~K})}\right)[\sigma(\mathrm{MPa})]^{2.5}[\mathrm{t}(\mathrm{s})]^{0.9}$.
\end{abstract}

${ }^{1}$ G. Li, Former Graduate Student at University of Illinois at Urbana-Champaign

2 B. G. Thomas, Professor, Department of Mechanical and Industrial Engineering, University of Illinois at Urbana-Champaign, 1206 W Green Street, Urbana, IL 61801

3 J. F. Stubbins, Professor, Department of Nuclear Engineering, University of Illinois at UrbanaChampaign, 103 S Goodwin Avenue, Urbana, IL 61801 


\section{INTRODUCTION}

Copper alloys, with their combination of high thermal conductivity and relatively high mechanical strength and toughness over a wide range of temperatures, are likely the best materials for complex structural applications subjected to conditions of extreme heat flux under load. Such applications range from molds for the continuous casting of steel[1-4] to the first wall of a fusion reactor ${ }^{[5-8]}$.

Continuous casting molds must withstand contact with molten steel and remove sufficient heat to continuously solidify a solid shell. To produce high-quality steel slabs, billets, and strip, a copper mold must maintain tight dimensional tolerances and consistent surface temperatures while being subjected to constant thermal cycling (due to both short and long liquid level changes). To be economical, it must survive many months with minimum wear while over 50,000 tonnes of steel is pulled through it. Most important of all, it must be 100\% safe from complete fracture, because contact between the molten steel and cooling water (separated by only a thin layer of copper) could be catastrophic.[2] New alloys are difficult to introduce owing to the difficulty of safely demonstrating their ability to satisfy these requirements.

The first wall of the proposed fusion reactor, ITER (International Thermonuclear Experimental Reactor) must be designed to face both thermal and nuclear radiation from million-degree plasma. This thin wall must maintain dimensional stability and withstand stresses induced by mechanical loads and temperature gradients as well as the irradiation creep and swelling induced by the high neutron fluence[6-8]. Achieving and proving reliable performance of the first-wall material is a key technical challenge that may determine the feasibility of commercial fusion reactors. Despite the widespread use of stainless steel in current nuclear reactors, copper alloys are the leading candidate materials for the ITER first wall.

The accurate prediction of the mechanical behavior and lifetime of the entire structure is crucial to applications such as these. To do this requires accurate models that include a robust characterization of material properties such as the thermal conductivity, thermal expansion coefficient, and mechanical constitutive relations. The latter includes elastic, plastic, and creep behavior, and fracture toughness, crack growth, and failure prediction under a variety of loading conditions, such as fatigue cycling. Furthermore, these constants must be represented in terms of fundamental constants that are still valid in complex geometries very different from the test specimens. 
This paper focuses on the material properties of commercially available copper alloys, optimized for both high strength and high thermal conductivity. They include precipitationhardened (PH) and oxide-dispersion-strengthened (ODS) alloys. Their chemical compositions, trade names, and manufacturers are listed in Table I.

Table I - Copper Alloys for High-strength, High Heat Flux Applications

\begin{tabular}{lll}
\hline Alloy (manufacturer) & Alloy type & Composition (wt \%) \\
\hline C10700[9] & Cu-Ag-P & $\mathrm{Cu}-0.1 \% \mathrm{Ag}-0.008 \% \mathrm{P}$ \\
CCZ (Kabelmetal) [10] & $\mathrm{Cu}-\mathrm{Cr}-\mathrm{Zr}(\mathrm{PH})$ & $\mathrm{Cu}-0.65 \% \mathrm{Cr}-0.10 \% \mathrm{Zr}$ \\
C17510 (Brush Wellman) [9] & $\mathrm{Cu}-\mathrm{Ni}-\mathrm{Be}(\mathrm{PH})$ & $\mathrm{Cu}-1.4$ to $2.2 \% \mathrm{Ni}-0.2$ to $0.6 \% \mathrm{Be}$ \\
GlidCop AL-x (SCM Metals) [11] & $\mathrm{Cu}-\mathrm{Al}_{2} \mathrm{O}_{3}$ & $\mathrm{Cu}-\mathrm{x} / 100 \% \mathrm{Al}\left(1.02 \times / 54 \% \mathrm{Al}_{2} \mathrm{O}_{3}\right)$ \\
E.g. GlidCop AL-15 (C15715) & $(\mathrm{ODS})$ & $\mathrm{Cu}-0.15 \% \mathrm{Al}$ as oxide particles \\
& & $\left(0.28 \% \mathrm{Al}_{2} \mathrm{O}_{3}\right)$ \\
\hline
\end{tabular}

Continuous casting molds are usually made of $\mathrm{Cu}-\mathrm{Ag}-\mathrm{P}, \mathrm{Cu}-\mathrm{Cr}-\mathrm{Zr}$, or sometimes $\mathrm{Cu}-\mathrm{Ni}$ Be alloys. Oxide-dispersion-strengthened alloys are leading candidates for the first wall of ITER, owing to their superior resistance to irradiation creep, relative to the PH alloys. In both of these applications, heat flux is on the order of $1 \mathrm{MW} \mathrm{m}^{-2}$, maximum operating temperature is $300-400^{\circ} \mathrm{C}$, and stress can reach $400 \mathrm{MPa}$.

The first objective of this paper is to review previous work on the property models of these four copper alloys, focusing on thermal creep and fatigue lifetime prediction. Then, fatigue experiments at the University of Illinois are reported on, with particular emphasis on a combined modeling approach to develop and evaluate a model for thermal creep of $\mathrm{Cu}-$ $0.28 \% \mathrm{Al}_{2} \mathrm{O}_{3}$. The ultimate objective is to build a database of property models for these and other alloy systems that can be implemented into accurate models of the complete structures.

\section{COPPER ALLOY PROPERTIES}

Several reviews on the properties of copper alloys have been published $[5,9,10,12]$ The PH alloys gain their strength from precipitation hardening, where intermetallic particles form during cooling. They can be cast and subsequently heat-treated, which is advantageous for structural components with complex geometry. The ODS alloys are strengthened by a fine dispersion of hard oxide particles. They cannot be cast, since the oxide particles would not remain uniformly dispersed in the liquid phase. Products of ODS alloys are only available in 
wrought form (sometimes produced by powder metallurgy technologies), and joined by brazing or diffusion bonding.

Zinkle reviewed the thermal and mechanical properties of copper alloys employed in high heat flux structural components for various thermomechanical treatments. ${ }^{[5]}$ The ODS alloys $\mathrm{Cu}-\mathrm{Al}_{2} \mathrm{O}_{3}, \mathrm{PH}$ alloys $\mathrm{Cu}-\mathrm{Cr}-\mathrm{Zr}$ and $\mathrm{Cu}-\mathrm{Ni}-\mathrm{Be}$, were found to have the best combination of high thermal conductivity $\left(>350 \mathrm{~W} \mathrm{~m}^{-1} \mathrm{~K}^{-1}\right)$ and high strength $(0.2 \%$ yield strength $>400$ $\mathrm{MPa}$ ) at room temperature, as shown in Figure 1(a). The PH alloys may soften due to precipitate coarsening (overaging) and recrystallization after extended exposure to temperatures above 400 ${ }^{\circ} \mathrm{C}$. The ODS alloys are resistant to both softening and irradiation creep, owing to their stable oxide particles.

Blanchet $[12]$ investigated the thermal and mechanical properties of a variety of copper alloys, including brass, tin copper, and aluminum copper alloys. The thermal conductivity at room temperature and the yield strength at $300{ }^{\circ} \mathrm{C}$, are presented in Figure 1(b) for the lowalloy coppers, which have the best properties.

\section{A. Constitutive Relations}

A major obstacle to performing an accurate thermal stress analysis is finding material constitutive equations that relate stress, strain, temperature, time, and strain rate, for arbitrary loading and temperature histories over the entire range of operating conditions experienced by the material. Finite element modeling approaches include unified elasto-visco-plastic, elasticplastic, and elastic-plastic-creep models.[13] The choice of model dictates the nature of property reporting.

Unified constitutive models characterize the instantaneous inelastic strain-rate response of a material point under arbitrary loading in terms of evolving state variables, which include temperature, stress, and structure. They can accurately simulate the coupling between plasticity and thermal creep even up to the solidification temperature.[14] For example, an increase in the slope of the stress-strain curve during a tensile test produced by work hardening or a decrease due to recovery can be reproduced in a model by corresponding increases or decreases to a structure parameter that represents dislocation density. The unified models require many additional tests, such as stress relaxation and variable loading tests to determine the parameters in the model and can be computationally expensive. 
Elastic-plastic models can be applied only when time-dependent plasticity and creep effects are small, or when the total strain rate is known, so that the appropriate stress-strain curves can be chosen a priori. Mechanical properties are extracted from standard tensile tests conducted at constant total strain rate and are defined in terms of an elastic modulus, yield stress, and plastic modulus, all of which may vary with temperature.

When the mechanical properties depend only slightly on strain rate, an elastic-plasticcreep model is appropriate. This model splits the inelastic strain into a rate-independent plastic part and a rate-dependent creep part which are assumed not to interact. In addition to the parameters defined in the elastic-plastic analysis, a creep strain function is needed. For high flux structures, the plastic loading is usually small, so this approach is reasonable. For the present work, temperature is intermediate and measurements of copper alloys consist mainly of standard tensile tests and creep tests, which are appropriate for this model.

\section{$B$ Yield Strength}

Yield strength decreases steadily with increasing test temperature. Yield strengths of ODS alloys are shown in Figure 2.[15-20] Most of these data were obtained on GlidCop AL-15 and Al-20, which have lower strengths than the Al-25 and Al-60 alloys. The room temperature yield strength varies between 300 and $600 \mathrm{MPa}$, mainly due to different amounts of cold work ( $31 \%$ to $80 \mathrm{CW}$ ) prior to testing.

Figure 3 shows the yield strengths of $\mathrm{Cu}-\mathrm{Cr}-\mathrm{Zr}$ alloys measured at $20-750{ }^{\circ} \mathrm{C}$. Gravemann et al[21] and Kabelmetal[10] investigated the properties of Elbrodur (commercial brand) $\mathrm{Cu}-\mathrm{Cr}-\mathrm{Zr}$, as shown in Figure 3.[5, 21] The yield strength of cold rolled $\mathrm{Cu}-\mathrm{Cr}-\mathrm{Zr}[22]$ is almost twice that of cast and aged material at room temperature, but drops faster with temperature, reaching similar strengths at $400{ }^{\circ} \mathrm{C}$. This is because the strength increase generated by prior cold work is lost at higher temperatures due to recrystallization and creep softening. For the same reason, the yield strengths of the silver bearing copper alloys at room temperature are similar to the others, but they weaken rapidly when the temperature exceeds $150{ }^{\circ} \mathrm{C}$. Thus, these nearly-pure, copper alloys are not as suitable for the high temperature applications of concern in this work.

\section{Thermal Creep}

Models to quantify creep behavior range from simple empirical correlations, which use accumulated strain and time to characterize the material structure, to complex models, which also incorporate intrinsic material properties, microstructural features, and microstructure 
evolution mechanisms such as the motion of vacancies, grain boundaries, and dislocations. Creep rates are dramatically reduced by the presence of particles, particularly if they are fine and uniformly distributed, which should also be modeled.

In simulating deformation of a complex structure, it is difficult and costly to accurately predict the microstructural features and their evolution. Thus, this work adopts the common empirical relation ${ }^{[14]}$ of strain rate, $\dot{\varepsilon}$, applied stress, $\sigma$, temperature, $\mathrm{T}$, and time, t:

$$
\dot{\varepsilon}=A \exp \left(-\frac{\mathrm{Q}}{\mathrm{RT}}\right) \sigma^{\mathrm{n}} \mathrm{t}^{\mathrm{m}}
$$

where $\mathrm{n}$ and $\mathrm{m}$ are the stress and time hardening exponents respectively, $\mathrm{Q}\left(\mathrm{kJ} \mathrm{mol}^{-1}\right)$ is the activation energy, $\mathrm{R},\left(8.314 \mathrm{~J} \mathrm{~mol}^{-1} \mathrm{~K}^{-1}\right)$, is the universal gas constant, and $\mathrm{A}$ is a constant with units of $\mathrm{MPa}^{\mathrm{n}} \mathrm{s}^{-(\mathrm{m}+1)}$..

This primary creep law simplifies to a steady state law when $\mathrm{m}$ is 0 . The steady state creep rate is the minimum rate measured during the second stage of a creep test.[23] It must be used with great caution when performing engineering calculations because both primary and tertiary creep rates are much larger and potentially more dangerous.

A quantitative comparison of conventional steady creep test data is presented in Figure 4, as a function of stress, temperature and alloy. Selected primary creep data is presented in Figure 5[1,3]. A curve through each set of data points was fit using Eq. [1], and the derived model parameters are presented in Table II, along with the corresponding experimental conditions. For a given material, the creep rate depends strongly on the applied temperature and stress level,[11, 14, 23-30]. In constructing the curve fits, $\mathrm{Q}$ and $\mathrm{n}$ values were adopted if they were reported, but all of the A values had to be calculated in this work.

For pure copper, $\mathrm{Q}$ for bulk lattice diffusion (i.e., vacancy diffusion) is $197 \mathrm{~kJ} \mathrm{~mol}^{-1}$ and $\mathrm{n}$ is 4.8.[25] Low alloy copper, such as $\mathrm{Cu}-\mathrm{Ag}-\mathrm{P}[1,3]$, exhibits similar thermal creep behavior to pure copper, so its $\mathrm{Q}$ and $\mathrm{n}$ values are also $197 \mathrm{~kJ} \mathrm{~mol}^{-1}$ and 4.8. The activation energy of relatively pure copper is reported to depend on elastic modulus E, stress exponent $n$, and temperature $\mathrm{T}$, according to: $[23,25]$

$$
Q=-R\left[\frac{\partial \ln \dot{\varepsilon}}{\partial(1 / T)}\right]_{\sigma=\text { const }}+\frac{n R T^{2}}{E}\left[\frac{d E}{d T}\right]
$$

Because E generally decreases with increasing temperature, the second term in this equation suggests that $\mathrm{Q}$ decreases with increasing temperature. 
Table II - Creep Strain Experimental Data for Copper Alloys

\begin{tabular}{|c|c|c|c|c|c|c|c|}
\hline Materials & $\begin{array}{l}\text { Particle } \\
\text { size } \\
(\mu \mathrm{m})\end{array}$ & $\begin{array}{c}\text { Test } \mathrm{T} \\
{ }^{\circ} \mathrm{C}\end{array}$ & $\begin{array}{l}\text { Applied } \\
\text { Stress } \\
\text { MPa }\end{array}$ & $\begin{array}{c}\text { Coefficient } \\
\mathrm{A}^{*} \\
\left(\mathrm{MPa}^{-\mathrm{n}_{\mathrm{s}}-\mathrm{m}-1}\right)\end{array}$ & $\begin{array}{l}\text { Activation } \\
\text { Energy Q } \\
\text { kJ-mol }^{-1} \mathrm{~K}^{-1}\end{array}$ & $\begin{array}{c}\text { Stress } \\
\text { Exponent } \\
\mathrm{n}\end{array}$ & $\begin{array}{c}\text { Time } \\
\text { Exponent } \\
\mathrm{m}^{*}\end{array}$ \\
\hline Pure copper $[25,29]$ & & $\begin{array}{l}400 \\
700\end{array}$ & $15-105$ & 38.8 & 197 & 4.8 & 0 \\
\hline $\begin{array}{c}\mathrm{Cu}-0.001 \% \mathrm{Ag}- \\
0.005 \% \mathrm{Fe}- \\
0.015 \% \mathrm{O}[23]\end{array}$ & 250 & $\begin{array}{l}600 \\
350 \\
400 \\
450 \\
500 \\
550 \\
600 \\
650 \\
700\end{array}$ & $\begin{array}{c}25-35 \\
20-100\end{array}$ & 0.006 & $\begin{array}{l}180 \\
180 \\
170 \\
155 \\
150 \\
135\end{array}$ & $\begin{array}{c}4.8^{*} \\
6.6\end{array}$ & -0.66 \\
\hline $\mathrm{Cu}-0.001 \%$ Ag[26] & 210 & 500 & $35-65$ & 800. & 186 & 3.8 & -0.385 \\
\hline $\begin{array}{l}\mathrm{Cu}-0.1 \% \mathrm{Ag}- \\
0.008 \% \mathrm{P}^{[1,9]}\end{array}$ & $\begin{array}{l}400-650 \\
\text { Anneal }\end{array}$ & 193 & $151-213$ & $1.16 \times 10^{5}$ & 197 & 5 & -0.5 \\
\hline $\begin{array}{l}\mathrm{Cu}-0.65 \% \mathrm{Cr}- \\
0.1 \% \mathrm{Zr}[1,2,9] * *\end{array}$ & & 216 & $183-282$ & $\begin{array}{l}7.56 \times 10^{11} \\
2.82 \times 10^{-22}\end{array}$ & $\begin{array}{l}197 \\
197\end{array}$ & $\begin{array}{c}3 \\
14\end{array}$ & $\begin{array}{c}-0.92 \\
0\end{array}$ \\
\hline $\begin{array}{l}\left.\mathrm{Cu}-.65 \% \mathrm{Cr}-.1 \% \mathrm{Zr}{ }^{4}\right] \\
\mathrm{Cu}-.45 \% \mathrm{Cr}- \\
0.19 \% \mathrm{Zr}[8]\end{array}$ & & $\begin{array}{l}538 \\
300\end{array}$ & $\begin{array}{c}- \\
110-213\end{array}$ & $\begin{array}{l}7.51 \times 10^{12} \\
1.80 \times 10^{-2}\end{array}$ & $\begin{array}{l}197 \\
197 *\end{array}$ & $\begin{array}{c}1.7 \\
5.3^{*}\end{array}$ & $\begin{array}{l}0 \\
0\end{array}$ \\
\hline $\mathrm{Cu}-2 \% \mathrm{Cr}-0.3 \% \mathrm{Zr}{ }^{[27]}$ & $\begin{array}{r}500-700 \\
\text { Anneal }\end{array}$ & $\begin{array}{c}400 \\
400 \\
400-500\end{array}$ & $\begin{array}{c}98 \\
218 \\
100-220\end{array}$ & $\begin{array}{l}3.25 \times 10^{-25} \\
1.31 \times 10^{-92}\end{array}$ & $\begin{array}{c}134 \\
112 \\
91-190^{*}\end{array}$ & $\begin{array}{c}15 \\
41 \\
15-41\end{array}$ & $\begin{array}{l}0 \\
0 \\
0\end{array}$ \\
\hline $\begin{array}{l}\mathrm{Cu}-2 \% \mathrm{Cr}-0.3 \% \mathrm{Zr}{ }^{[28]} \\
\mathrm{Cu}-\mathrm{Cr}-\mathrm{Zr}{ }^{[30]}\end{array}$ & 0.7 & $\begin{array}{c}400-500 \\
300\end{array}$ & $\begin{array}{c}80-155 \\
210-300\end{array}$ & $\begin{array}{c}- \\
4.64 \times 10^{-8}\end{array}$ & $\begin{array}{c}210-260 \\
197^{*}\end{array}$ & $\begin{array}{c}11-29 \\
7.4^{*}\end{array}$ & $\begin{array}{l}0 \\
0\end{array}$ \\
\hline $\begin{array}{l}\mathrm{Cu}-1.4 \text { to } 2.2 \% \mathrm{Ni}- \\
0.2 \text { to } 0.6 \% \mathrm{Be}^{[1,9]}\end{array}$ & $\begin{array}{c}\text { 400-600 } \\
\text { Aging }\end{array}$ & 229 & $180-372$ & $1.07 \times 10^{9}$ & 197 & $2.5^{*}$ & -0.75 \\
\hline $\begin{array}{l}\mathrm{Cu}-\mathrm{Al}_{2} \mathrm{O}_{3} \text { (GlidCop } \\
\mathrm{AL}-25)[11]\end{array}$ & $\begin{array}{c}1000 \\
\text { Anneal }\end{array}$ & 350 & $70-130$ & $1.28 \times 10^{-13}$ & $197 *$ & 12.64 & 0 \\
\hline $\begin{array}{c}\mathrm{Cu}-\mathrm{Al}_{2} \mathrm{O}_{3} \text { (GlidCop } \\
\mathrm{AL}-15)[25]\end{array}$ & $\begin{array}{l}0.60 \\
0.65\end{array}$ & $\begin{array}{l}472 \\
725\end{array}$ & $\begin{array}{c}100-130 \\
30-50\end{array}$ & $\begin{array}{l}2.3 \times 10^{-49} \\
9.5 \times 10^{-10}\end{array}$ & $\begin{array}{l}257.6 \\
248.9\end{array}$ & $\begin{array}{c}30 \\
10.6\end{array}$ & $\begin{array}{l}0 \\
0\end{array}$ \\
\hline $\begin{array}{c}\mathrm{Cu}-\mathrm{Al}_{2} \mathrm{O}_{3} \text { (GlidCop } \\
\text { AL-15) }\end{array}$ & & 400 & $130-200$ & $7.6 \times 10^{-11}$ & $197^{*}$ & 9.8 & 0 \\
\hline $\mathrm{Cu}-\mathrm{Al}_{2} \mathrm{O}_{3}[24]$ & & 650,850 & $55-241$ & - & 512 & $15-22$ & 0 \\
\hline $\mathrm{Cu}-\mathrm{Al}_{2} \mathrm{O}_{3}[24]$ & & 650 & $130-210$ & - & - & $23-26$ & 0 \\
\hline $\mathrm{Cu}-\mathrm{Al}_{2} \mathrm{O}_{3}[24]$ & & 550,650 & $17-27$ & - & 368 & $30-49$ & 0 \\
\hline
\end{tabular}

*These values were found by fitting the referenced experimental data to Eq. [1].

**First row is a primary creep law (with a threshold stress of $159 \mathrm{MPa}$, which must be subtracted from $\sigma$ before using the equation). Second row is a steady creep law, (valid at times greater than the critical time when primary and secondary creep strains are equal). 
Dispersion strengthened copper alloys $\mathrm{Cu}-\mathrm{Al}_{2} \mathrm{O}_{3},[11,18,24,25]$ at high stresses and low temperature have $\mathrm{n}$ values of 4-8, and Q around $197 \mathrm{~kJ} \mathrm{~mol}^{-1}$. However, at low stresses, $\mathrm{n}$ increases to as high as 20-100, and Q reaches 3 times as high as that for bulk lattice diffusion. Also, at high temperature, a threshold stress for ODS copper alloy creep was reported.[28] Creep strain is negligible when the applied stress is below this threshold stress.

For $\mathrm{Cu}-\mathrm{Cr}-\mathrm{Zr}$ alloys, Q is reported to range from 100 to $197 \mathrm{~kJ} \mathrm{~mol}^{-1}$, if the annealing temperature is below $600{ }^{\circ} \mathrm{C}$. [28] For a high annealing temperature of $700{ }^{\circ} \mathrm{C}, \mathrm{Q}$ varies widely (from 66 to $327 \mathrm{~kJ} \mathrm{~mol}^{-1}$ ), depending on the stress and strain levels. The stress exponent $\mathrm{n}$ for $\mathrm{Cu}-\mathrm{Cr}-\mathrm{Zr}[28]$ increases from about 4 to 29 , as the test temperature rises from room temperature to $500{ }^{\circ} \mathrm{C}$, for stresses of 80 - $155 \mathrm{MPa}$. Beryllium copper alloys, such as $\mathrm{Cu}-\mathrm{Ni}-\mathrm{Be},[1,3]$ have the highest thermal creep resistance among the copper alloys studied in this work. As shown in Figures 4 and 5, its stress exponent is only 2.5 .

\section{Cyclic Deformation}

Loading due to thermal-cycling in a constrained region of a structure can be represented by constant strain-amplitude mechanical loading at a fixed temperature. $[31,32]$ Plastic strain can be held constant during each cycle, by controlling the instantaneously measured response. For a fully-reversed, strain-controlled fatigue test, the stress amplitude decreases with time for a cyclic softening material. This behavior is common at elevated temperature, as creep strain due to dislocation climb and grain boundary movement occurs during each cycle. Eventually a stable hysteresis loop is achieved. The results of many such tests can be plotted together in a cyclic stress-strain curve, such as for the two alloys in Figure 6. Each data point is taken from a single fully-reversed strain-controlled fatigue test at ambient temperature. At high temperatures, the materials under analysis are cyclic softening, so the stress values in a constructed cyclic stressstrain plot are lower than those found in the static stress-strain curve (given in the first cycle).

In simulating the hardening or softening phenomena observed in cyclic tests, a complete constitutive model of cyclic plasticity should specifically account for: (1) the Bauschinger effect, where the yield stress decreases after a load reversal, (2) cyclic creep ratchetting, where plastic strain accumulates in each cycle of a stress-controlled fatigue test with nonzero mean stress, and (3) stress relaxation, where the stress in a strain-controlled test with a nonzero mean stress will tend toward zero with the progression of cyclic deformation. Two popular modeling approaches are "isotropic hardening", where the yield stress increases with the absolute accumulated strain, 
and "kinematic hardening," where the yield stress evolves and is able to reproduce Bauschinger effects and stable hysteresis loops.[33,34] This work investigates the idea that these simple timeindependent elastic-plastic models, when combined with an appropriate creep law, can approximately reproduce many of the important phenomena encountered in cyclic loading.

\section{E Fatigue Life}

Fatigue failure may occur in structures subjected to cyclic stresses, at stress levels considerably below the yield strength. Fatigue lifetime is lower at higher temperatures, especially when stress levels are high enough to generate significant inelastic strain in each cycle and cause low cycle fatigue. Fatigue lifetime prediction models have been based on inelastic strain, total strain, stress and other approaches. Common empirical correlations to predict fatigue lifetime include the Basquin Law, [35] the Coffin-Manson relation, [36] the Coffin-Halford formula,[37] and Neuber's rule.[35] In this work, the inelastic strain is much higher than the elastic strain, so a simplified Coffin-Manson approach,[36, 38] appears most appropriate:

$$
\frac{\Delta \varepsilon}{2}=\varepsilon_{f}^{\prime}\left(2 N_{f}\right)^{c}
$$

where $\Delta \varepsilon / 2$ is either the total strain amplitude or the inelastic strain amplitude, $\varepsilon_{\mathrm{f}}$ is the empirical fatigue ductility coefficient, $2 \mathrm{~N}_{\mathrm{f}}$ is the number of reversals to failure, and $\mathrm{c}$ is the empirical fatigue ductility exponent. For an ODS copper alloy, the value of $\mathrm{c}$ is approximately 0.6 , and $\varepsilon_{\mathrm{f}}$ is $0.56^{[29]}$, based on the inelastic strain amplitude.

Previous work has investigated low-cycle fatigue of copper,[31] [39] copper/stainless steel or copper/beryllium welds, $[40,41]$ oxygen free high conductivity copper (OFHC), [42, 43] $\mathrm{Cu}-\mathrm{Al}_{2} \mathrm{O}_{3}[8,31,32,40] \mathrm{Cu}-\mathrm{Cr}-\mathrm{Zr}[8]$ and $\mathrm{Cu}-\mathrm{Ni}-\mathrm{Be}$ alloys.[3, 40] Measurements of fatigue lifetime for these copper alloys are shown in Figures 7(a) and 7(b). Results from recent isothermal bending experiments are given in Figure 8.[40] These results quantify the significant effect that increasing temperature has on lowering the fatigue lifetime. Fatigue life prediction is further complicated when the loading is thermo-mechanical in origin, so the structure is not isothermal. For example, the failure of continuous casting molds in service occurred after fewer cycles than predicted with an isothermal fatigue life model.[4] The importance of these high temperature effects in limiting fatigue lifetimes, $[29,31,41]$ the difficulty of predicting lifetimes, and the paucity of quantitative data provide a great incentive for more work in this area. 


\section{Fatigue Experiments}

Fatigue experiments were conducted on bimetallic copper/stainless-steel plates. Specifically, four-point compressive load and constraint conditions were applied on the bending test specimens shown in Figure 9. The 101.6 x 12.7 x $12 \mathrm{~mm}^{3}$ specimens were made of a 6-mm thick wrought copper alloy plate, GlidCop AL-15 (Cu with $0.28 \% \mathrm{Al}_{2} \mathrm{O}_{3}$ particles) explosively bonded to a 6-mm thick wrought $316 \mathrm{~L}$ stainless steel plate. These tests were designed to approximate the geometry, fabrication methods, and loading conditions proposed for the first wall of the ITER fusion reactor. Sinusoidal loading conditions (load control) were applied with a minimum to maximum stress ratio (i.e., R-ratio) of 0.1. Vertical y-displacement at the load position (point B) was recorded continuously. A summary of test conditions and results is given in Table III.

Table III - Fatigue Test Measurements

\begin{tabular}{|c|c|c|c|c|c|c|c|}
\hline \multirow[t]{2}{*}{ Specimen } & \multirow[t]{2}{*}{$\begin{array}{c}\text { Test } \\
\text { temperature } \\
\left({ }^{\circ} \mathrm{C}\right)\end{array}$} & \multirow[t]{2}{*}{$\begin{array}{l}\max . \\
\text { Load } \\
(\mathrm{kN})\end{array}$} & \multirow[t]{2}{*}{$\begin{array}{l}\text { Frequency } \\
\qquad(\mathrm{Hz})\end{array}$} & \multirow[t]{2}{*}{$\begin{array}{l}\text { Lifetime } \\
\text { cycles to } \\
\text { failure }\end{array}$} & \multirow{2}{*}{$\begin{array}{c}\text { Estimated } \\
\text { Max tensile } \\
\text { stress } \\
(\mathrm{MPa})\end{array}$} & \multicolumn{2}{|c|}{$\begin{array}{c}\text { Indentation } \\
\text { at four } \\
\text { points }(\mathrm{mm})\end{array}$} \\
\hline & & & & & & $\mathrm{Cu}$ & SS \\
\hline A-1 & ambient & -7.7 & * & 336401 & 355 & $*$ & $*$ \\
\hline A-2 & ambient & $*$ & $*$ & $>1500000$ & 213 & $*$ & $*$ \\
\hline A-3 & ambient & -16 & $*$ & $*$ & 450 & $*$ & $*$ \\
\hline A-4 & ambient & -8.5 & 5 & 949240 & 284 & 0.05 & 0.05 \\
\hline A-5 & ambient & -8.5 & 5 & 808470 & 250 & 0.04 & 0.02 \\
\hline A-6 & ambient & -13.5 & 2.5 & 112916 & 500 & 0.10 & 0.10 \\
\hline A-7 & ambient & -6.5 & 5 & 2766221 & 225 & 0.03 & 0.02 \\
\hline A-11 & 250 & -7.25 & 2.5 & $>3000000$ & 250 & 0.08 & 0.02 \\
\hline A-12 & 250 & -9.5 & 5 & $>6388821$ & 325 & 0.08 & 0.05 \\
\hline A-13 & 250 & -11.5 & 5 & 2074350 & 400 & $*$ & $*$ \\
\hline A-14 & 250 & -13 & 2.5 & 34876 & 450 & 0.13 & 0.10 \\
\hline A-15 & 250 & -13 & 2.5 & 49265 & 450 & 0.12 & 0.10 \\
\hline
\end{tabular}

* not available

At low load, the loading and unloading curves follow the same load-displacement path during each cycle, indicating elastic behavior. Experiments performed at higher load produce large plastic strains in the first cycle, as evidenced by differences between the loading and unloading curves. Subsequent cycles follow the same path, indicating that the initial plastic strain hardening increases the yield stress sufficiently for subsequent stresses to be entirely elastic. Experiments at higher temperature experience inelastic strain in each cycle, indicating thermally-induced creep and the phenomenon of thermal ratchetting. 
Examination of the final shapes of the test specimens found them distorted in two different ways. First, the bars appeared "sagged", with more deformation at the center of the specimens tested at higher load and / or temperature. This deformation provides evidence for the accumulation of residual plastic strains, which occur during each loading cycle. Secondly, each of the four points where a load or constraint was applied had a slight indentation. About $40 \%$ of the depth of each indentation was produced in the first loading cycle. Again, the depth increased with load and temperature. Indentations at the constraint positions in the copper were slightly deeper than that at the load positions in the stainless steel, presumably because the copper is softer. Fatigue failure generally occurred at a crack perpendicular to the surface that was initiated after a large number of cycles at the bottom copper surface. Occasional cracks turned to propagate along the interface. The crack typically grew either to or through the interface (at low loads). These results suggest that the interface bond may be stronger than the copper alloy, which deforms due to thermal creep.

\section{Model of Fatigue Experiments}

\section{A Finite-Element Model Description}

The fatigue experiments discussed in the previous section were simulated using a twodimensional finite-element stress model, solved with ABAQUS.[33] Since the temperature range under study is below $400{ }^{\circ} \mathrm{C}$, and property data was not available, unified models were not employed. Instead, the simpler conventional elastic, elastic-plastic, elastic-creep, and elastic-plastic-creep models were investigated. The simulation domain, load and constraint conditions for the test bar specimens are given in Figure 9. The model employs a 32 x 26 mesh of standard 4-node, two-dimensional plane-strain finite elements (CPE4 in ABAQUS[33]). A mesh refinement study revealed that further refinement increased stress predictions by less than $2 \%$. Both the isotropic and kinematic hardening models give the same results, since stresses in these bending tests never exceed the yield in reverse loading. Most of the assumed mechanical properties are given in Table IV, and are based on the reviewed literature for copper and stainless steel.[44] In addition, a Poisson ratio $v$ of 0.343 and plastic modulus of $11 \mathrm{GPa}$ was assumed for copper. Values of 0.283 and $8 \mathrm{GPa}$ were assumed for stainless steel. 
Table IV - Material properties

\begin{tabular}{ccccc}
\hline $\begin{array}{c}\text { Temperature } \\
\left({ }^{\circ} \mathrm{C}\right)\end{array}$ & $\begin{array}{c}\text { Thermal } \\
\text { Conductivity } \\
\mathrm{k}\left(\mathrm{Wm}^{-1} \mathrm{~K}^{-1}\right)\end{array}$ & $\begin{array}{c}\text { Thermal } \\
\text { Expansion } \\
\alpha\left({ }^{\circ} \mathrm{C}^{-1}\right)\end{array}$ & $\begin{array}{c}\text { Elastic } \\
\text { Modulus } \\
\mathrm{E}(\mathrm{GPa})\end{array}$ & $\begin{array}{c}\text { Yield } \\
\text { Stress }(0.2 \%) \\
\mathrm{YS}(\mathrm{MPa})\end{array}$ \\
\hline GlidCop AL-15 & & & & \\
20 & 344 & $16.6 \times 10^{-6}$ & 130 & 410 \\
250 & 317 & $17.8 \times 10^{-6}$ & 130 & 393 \\
Stainless Steel & & & & \\
20 & 16.0 & $16.0 \times 10^{-6}$ & 200 & 207 \\
250 & 18.15 & $17.2 \times 10^{-6}$ & 140 & 200
\end{tabular}

\section{B Comparison with Analytical Solution and Elastic Experiments}

The first simulation was conducted with a small maximum load of only $3.088 \mathrm{kN}$, to produce only elastic behavior. First, results from this elastic simulation were verified with an analytical solution (see Appendix). Axial (x-stress) at the bottom center of the specimen (copper) is $221 \mathrm{MPa}$ tension, while the top (stainless steel) is about $229 \mathrm{MPa}$ compression. The neutral axis (where stress is zero) is very close to the interface of the copper and stainless steel, owing to the similarity of the two elastic moduli (130 and $140 \mathrm{GPa}$ ). The maximum vertical (y) displacement at the load position (point B in Figure 9) and maximum strain position (point C) are $0.13 \mathrm{~mm}$ and $0.15 \mathrm{~mm}$ respectively. The compliance at point $\mathrm{B}$ is then $0.13 \mathrm{~mm} / 3.088 \mathrm{kN}$ $=4.2 \times 10^{-8} \mathrm{~m} \mathrm{~N}^{-1}$, which is the same as the analytical solution.

Next, the slopes of the elastic experimental load-displacement curves were measured. The load-extension curve in the test bar followed almost the same path during every cycle. The tiny observed changes might be attributed to small amounts of cyclic softening or hardening of the stainless steel. More importantly, the average slope of those curves matched the model predictions, indicating that the choice of elastic modulus and Poisson ratio were reasonable.

\section{Comparison with Fatigue Experiments}

Next, an elastic-plastic calculation was performed using the properties in Table IV for the conditions of test A-14 in Table III. The x-stress profile predicted by ABAQUS through the center of the specimen at maximum load is given in Figure 10. The top layer of the stainless steel is in compression, while the bottom layer of copper is in tension, except for a small region near the interface of the two materials. The neutral axis is displaced from the copper / stainlesssteel interface almost $1.0 \mathrm{~mm}$ into the copper. This is because the steel has more plastic strain, owing to its lower yield strength, so supports less load. The bottom $2 \mathrm{~mm}$ of the copper and the 
top $4 \mathrm{~mm}$ of the stainless steel deform plastically. This naturally lowers the maximum stress levels. In the central region, the elastic solution matches the finite element model results. The slopes in the two material zones are nearly the same, and the stress across the interface is almost continuous, owing to the similarity of the two elastic moduli.

Finally, elastic-plastic-creep simulations were conducted with the material properties presented in Table IV and compared with the measurements. The x-stress and equivalent plastic strain contours calculated at maximum load in a typical specimen (A-14) are presented in Figure 11. As expected, high axial (x-direction) tension was found at the bottom of the copper alloy layer (448 MPa maximum) and high compression at the top of the stainless steel layer. Inelastic strains are greatest at the top and bottom surfaces.

The load was plotted as a function of relative displacement at the load position (including the local indentation effect) to compare the simulation results with the experimental record of fatigue test A-14, as shown in Figures 12 and 13(a). The slopes of the loaddisplacement loops are related to the elastic modulus of the materials. Except for the first loop, all slopes of the load-displacement loops from the ABAQUS model match the fatigue test results. The slight underprediction of the measured displacement for the first half load cycle is likely due to the underprediction of the indentation and the take-up of play in the testing equipment.

The successive increases of the maximum displacement of test A-14 are attributed to thermal ratchetting, because inelastic thermal creep is significant in this copper alloy at the elevated test temperature of $250{ }^{\circ} \mathrm{C}$. Although the $2.5 \mathrm{~Hz}$ frequency of this test is very fast, creep is still believed to be the dominant phenomenon. The importance of creep would be expected to be even more important, if the fatigue cycling frequency were lower. Plasticity is significant only during the first cycle, and is followed by a rapid "shakedown" period. The accumulated displacement in each cycle decreases rapidly with increasing cycles. This might be due to the decrease in creep rate in the primary creep regime.

The trends of both the predictions and fatigue test results are the same. The maximum deflection, at the center of the specimen, is $1.07 \mathrm{~mm}$. This is close to the $1.0 \mathrm{~mm}$ measured in specimen A-14. Plastic strain is predicted to be large in the first half loading cycle $(0.2 \mathrm{~mm}$ of the $0.81 \mathrm{~mm}$ total displacement at the load position), and then drops rapidly to reach zero in subsequent cycles. Although the test was conducted in load control, the maximum load in the first cycle did not reach the prescribed value of $-13 \mathrm{kN}$. This accounts for the difference between the simulation and the measured stress after the first half cycle. The actual indentation 
in the first cycle of test A-14 is estimated to be about $0.06 \mathrm{~mm}$, considering that a significant fraction of the final accumulated indentation of $0.13 \mathrm{~mm}$ is expected in the first cycle. The calculated depth of the indentation after the first half-cycle is $0.04 \mathrm{~mm}$, which compares reasonably with the measurement, considering the course size of the finite-element mesh near the indentation. The thermal creep law used in the simulation underpredicts the accumulated displacement at long times (large cycles) for the test at $450 \mathrm{MPa}$ (A-14), while it slightly overpredicts for the test at $400 \mathrm{MPa}(\mathrm{A}-13)$. This can be seen by examining Figure 13, where each large symbol on the predicted curve corresponds with a series of smaller symbols which define the measured response at a particular selected cycle. The discrepancies correspond with the mismatch between the new thermal creep law and the estimated creep rates, which are compared in Figure 14 and discussed in the next section.

\section{Thermal Creep Law For Glidcop AL-15 Alloy}

No creep law was available from the literature for the GlidCop AL-15 alloy, so constants for the creep law were chosen such that the simulations described in the previous section were able to reasonably match the fatigue test measurements. This was achieved via the following steps:

(1). First, the load-position data recorded for the high-temperature tests A-11 to A-14 were converted to displacement-time curves, knowing the number of load cycles and their frequency. Relative displacement was measured at the load position (point B) at the point of maximum load in each cycle. The average displacement was crudely estimated by dividing the total increase in displacement between two recorded cycles by the number of cycles between them.

(2). Next, the displacement/time curves were converted to creep-rate / time curves (Figure 14). To determine the relation between the displacement and the creep rate, the transient elastic-creep finite-element model described in the previous section was applied to simulate a single load cycle under conditions of both constant loading and sinusoidal loading. For typical test conditions, the result was that the creep strain accumulated over a complete sinusoidal cycle is the same as that for the constant maximum load applied over about half of the cycle period. The exact relation is independent of load, but varies with frequency. Using the appropriate relation for each test, an input creep rate was found to match each corresponding increase in the displacement at B, so the creep-rate / time curves could be constructed. For the tests with different periods, additional linear conversion was needed to make the total creep time the same. 
(3). Finally, the creep rates were paired with the average time of the two recorded cycles. Creep rate curves for other $\mathrm{Cu}$ alloys are supplied on the same graph for comparison. These curves from Thomas ${ }^{[1,2]}$ are time-, stress-, and temperature-dependent primary creep laws for copper alloys, as given in Table II and shown in Figure 5. The stress exponent was found from the slope of $\ln (\dot{\varepsilon}) \sim \ln (\sigma)$ curves of the four $250{ }^{\circ} \mathrm{C}$ tests at long time. The accuracy of this calibration is illustrated in Figure 14. The new creep function for copper - 0.28 $\% \mathrm{Al}_{2} \mathrm{O}_{3}$ alloy or $\mathrm{Cu}-\mathrm{AL}-15$ is:

$$
\dot{\varepsilon}\left(\mathrm{s}^{-1}\right)=1.43 \times 10^{10} \exp \left(-\frac{197000}{8.31 \mathrm{~T}(\mathrm{~K})}\right)[\sigma(\mathrm{MPa})]^{2.5}[\mathrm{t}(\mathrm{s})]^{-0.9}
$$

This simple power law creep correlation in Eq. [4] roughly predicts the measured creep rate over this range of load $(7.25$ to $13 \mathrm{kN})$, stress (250 to $450 \mathrm{MPa})$, and time $\left(0.1-10^{4}\right.$ seconds), at least at $250{ }^{\circ} \mathrm{C}$. Figure 14 compares the constant log slope of the power law curve with the gradually steepening curve from the experiments. In all cases, the creep rates tend to very small values at large test cycles (long times). The small steady values expected for secondary creep were not reached in only $10^{4}$ seconds. Creep rates predicted with the new creep law compare reasonably with those of previous creep laws, as shown in Figure 14.

\section{Discussion}

Four point bending fatigue tests were performed on layered copper-stainless steel specimens, and thermal ratchetting was observed for the tests at $250{ }^{\circ} \mathrm{C}$. The tests were then simulated using an elastic-plastic-creep finite-element stress model. A primary thermal creep law for the $\mathrm{Cu}-0.28 \% \mathrm{Al}_{2} \mathrm{O}_{3}$ copper alloy was found by fitting the four point bending fatigue tests. The ratchetting displacements and local depressions predicted using this equation in an elastic-plastic-creep model approximately matched those from the fatigue test results.

No attempt was made to extract a failure correlation from the present data because the failure mechanisms are believed to be more complex than a simple correlation could reasonably be extrapolated from. Cracks sometimes ran to the interface and then turned to run along the interface. At other times, the cracks ran to the neutral axis of the specimen, before arresting or turning. The relationship between the location of the neutral axis of the specimen to the interface between layers appears to be critical in understanding failure of a layered specimen.

This combined experimental-modeling approach is a powerful method to tackle complex problems. Much more work is needed on the specific problem of finding mechanical properties to enable the prediction of thermal fatigue life of copper alloy components. Finite element 
simulations of the test specimens, such as those conducted in the present work, should be routinely conducted to help analyze the results of fatigue and other complex experiments in the future.

\section{CONCLUSIONS}

This paper reviews quantitatively, the thermal creep laws and fatigue lifetime correlations of the copper alloys $\mathrm{Cu}-\mathrm{Ag}-\mathrm{P}, \mathrm{Cu}-\mathrm{Cr}-\mathrm{Zr}, \mathrm{Cu}-\mathrm{Ni}-\mathrm{Be}$, and $\mathrm{Cu}-\mathrm{Al}_{2} \mathrm{O}_{3}$. This work then demonstrates how experiments and modeling should be performed together to develop property data for the analysis of complex structures:

(1) Design and perform experiments where the sample geometry, material and load conditions match as close as possible to the critical portions of the real structure of interest. In this work, four-point bend fatigue specimens consisting of layers of copper and stainless steel are loaded sinusoidally to match typical conditions expected in high heat flux structures.

(2) Simulate the experiments with a realistic computational model and modify the input parameters and models until the predictions match the test results. In this work, an elasticplastic-creep finite-element model is applied and a new power-law expression is developed to describe primary creep of $\mathrm{Cu}-0.28 \% \mathrm{Al}_{2} \mathrm{O}_{3}$.

(3) Apply the computational model to the real complex structure of interest and use predictions such as the mechanical behavior and fatigue life to optimize the design and ensure safety. The present model is applied to simulate the mold of a continuous casting machine, and the first wall of ITER, in work described elsewhere.[2, 45]

\section{APPENDIX ANALYTICAL SOLUTION FOR BENDING IN ELASTIC REGION}

The stress distribution calculated through the thickness of the bending test specimen matches the following analytical solution in the linear elastic region. Based on the geometry defined in Figure 9, and assuming maximum load, $\mathrm{P}_{\max }=3.088 \mathrm{kN}, \mathrm{E}_{\mathrm{cu}}=130 \mathrm{GPa}, \mathrm{E}_{\mathrm{ss}}=140 \mathrm{GPa}$, the maximum stresses in the stainless steel, $\sigma_{\mathrm{ss}}$, and copper, $\sigma_{\mathrm{Cu}}$, are:

$$
\begin{gathered}
\sigma_{\mathrm{ss}}=\frac{M h_{1}}{I_{\text {eqss }}}=\frac{P_{\text {max }} L^{\prime}}{4} \frac{E_{\mathrm{ss}} h_{1}}{(E I)_{\text {eff }}}=-229 \\
\sigma_{\mathrm{cu}}=\frac{M h_{2}}{I_{\text {eqcu }}}=\frac{P_{\text {max }} L^{\prime}}{4} \frac{E_{\text {cu }} h_{2}}{(E I)_{\text {eff }}}=+221
\end{gathered}
$$


Where $(E I)_{\text {eff }}=\left(I_{\mathrm{ss}} \mathrm{E}_{\mathrm{ss}}+\mathrm{I}_{\mathrm{cu}} \mathrm{E}_{\mathrm{cu}}\right)=2.466 \mathrm{X} 10^{5} \mathrm{GPa} \mathrm{mm}{ }^{-4}, \mathrm{I}_{\mathrm{ss}}=\mathrm{H}_{1}{ }^{3} \mathrm{~b} / 12+\mathrm{H}_{1}\left(\mathrm{~h}_{1}-0.5 \mathrm{H}_{1}\right)^{2} \mathrm{~b}$ $=864\left(\mathrm{~mm}^{4}\right), \mathrm{I}_{\mathrm{cu}}=\mathrm{H}_{2}{ }^{3} \mathrm{~b} / 12+\mathrm{H}_{2}\left(\mathrm{~h}_{2}-0.5 \mathrm{H}_{2}\right)^{2} \mathrm{~b}=966\left(\mathrm{~mm}^{4}\right)$

$$
\begin{aligned}
& \mathrm{h}_{1}=\frac{0.5 \mathrm{E}_{\mathrm{ss}} \mathrm{H}_{1}^{2}+\mathrm{E}_{\mathrm{cu}} \mathrm{H}_{1} \mathrm{H}_{2}+0.5 \mathrm{E}_{\mathrm{cu}} \mathrm{H}_{2}^{2}}{\mathrm{E}_{\mathrm{ss}} \mathrm{H}_{1}+\mathrm{E}_{\mathrm{cu}} \mathrm{H}_{2}}=5.89 \mathrm{~mm} ; \mathrm{h}_{2}=\mathrm{H}_{1}+\mathrm{H}_{2}-\mathrm{h}_{1}=6.11 \mathrm{~mm} \\
& \delta_{\mathrm{A}}=\frac{\mathrm{P}_{\max } \mathrm{a} / 2}{6(\mathrm{EI})_{\text {eff }}}\left(4 \mathrm{a}^{2}-3 \mathrm{~L}^{\prime} \mathrm{a}\right)=0.13 \mathrm{~mm} ; \delta_{\max }=\frac{\mathrm{P}_{\max } \mathrm{a} / 2}{24(\mathrm{EI})_{\text {eff }}}\left(4 \mathrm{a}^{2}-3 \mathrm{~L}^{\prime 2}\right)=0.15 \mathrm{~mm}
\end{aligned}
$$

In the elastic region, vertical displacement $\delta$ is directly proportional to the load, so their ratio, the theoretical compliance of the specimen, is a constant:

$$
\left|\frac{\delta_{\mathrm{A}}}{\mathrm{P}_{\max }}\right|=\left|\frac{\left(4 \mathrm{a}-3 \mathrm{~L}^{\prime}\right) \mathrm{a}^{2}}{12(\mathrm{EI})_{\text {eff }}}\right|=4.21 \times 10^{-8} \mathrm{~m} \mathrm{~N}^{-1}
$$

\section{ACKNOWLEDGEMENTS}

The authors would like to acknowledge the support of McDonnell Douglas and the Continuous Casting Consortium at the University of Illinois. Special thanks are also due to Peter Kurath, who performed the fatigue experiments, and to the National Center for Supercomputing Applications for providing computing time and the ABAQUS program. 


\section{REFERENCES}

1. B.G. Thomas: Effect of Copper Properties on Thermal Distortion of Continuous Slab Casting Molds, University of Illinois at Urbana-Champaign, Report to Brush Wellman, Cleveland, OH, August 26, 1993.

2. B.G. Thomas, G. Li, A. Moitra and D. Habing: "Analysis of Thermal and Mechanical Behavior of Copper Molds During Continuous Casting of Steel Slabs", ISS Transactions, 1998, vol. 25, (10), pp. 125-143.

3. J.O. Ratka and W.D. Spiegelberg: "A High Performance Beryllium Copper Alloy for Magnet Applications", IEEE Transaction on Magnetics, 1994, vol. 30, (4), pp. 18591862.

4. T.G. O'Connor and J.A. Dantzig: "Modeling the Thin-Slab Continuous-Casting Mold", Metallurgical Transaction B, 1994, vol. 25B, pp. 443-457.

5. $\quad$ S.J. Zinkle and S.A. Fabritsev: "Copper Alloys for High Heat Flux Structure Applications", Atomic and Plasma-material Interaction Data for Fusion, 1994, vol. 5.

6. J.F. Stubbins, D.C. Drockelman, P. Kurath, K.D. Leedy, G. Li, J.L. McAfee, G.D. Morgan, K.T. Stattery, B.G. Thomas and G.W. Willy: Cu-Alloys to SS Joining Techniques Assessment, Development and Recommendation, Joint Mechanical Testing, Fracture Mechanism and Cyclic Fatigue Tests of Cu/SS and Cu/Be Welds, University of Illinois at Urbana-Champaign, Report No. ITER/US/95/IV-BL-20, Final Report of U.S. ITER Task T8 (CY1995), December 1995.

7. P. Fenici, D.J. Boerman, G.P. Tartaglia and J.D. Elen: "Effect of Fast-Neutron irradiation on Tensile Properties of Precipitation-Hardened CU-Cr-Zr alloy", Journal of Nuclear Materials, 1994, vol. 212-215, pp. 399-403.

8. I.V. Gorynin, S.A. Fabritsiev and V.V. Rybin: "Radiation Resistant Properties of Copper Alloys Intended for Fusion Reactor Applications", J. Nucl. Mater., 1992, vol. 191-194, pp. 401-406.

9. R.J. Weggel, J.O. Ratka, W.D. Spiegelberg and Y. Sakai: "Strength of Hycon 3 HP Be$\mathrm{Cu}$ and Other Copper Alloys from $20^{\circ} \mathrm{C}$ to $200^{\circ} \mathrm{C}$ ", IEEE Transactions on Magnetics, 1994, vol. 30, (4), pp. 2188-2191.

10. Kabelmetal: Elbrodur $\mathrm{Cu}-\mathrm{Cr}-\mathrm{Zr}$ alloys, Technical data brochure on $\mathrm{Cu}$ alloy moulds for continuous casting, March, 1997.

11. R.R. Solomon, A.V. Nadkarni and J.D. Troxell: Personal Communication, University of Illinois at Urbana-Champaign, Urbana, IL, October 3, 1995. 
12. J.-P. Blanchet: "Copper Metallurgy-Application to Continuous Casting Moulds", Revue de Metallurgie-CIT, 1982, vol. 82, (Mars), pp. 237-252.

13. P.F. Kozlowski, B.G. Thomas, J.A. Azzi and H. Wang: "Simple Constitutive Equations for SSteel at High Temperature", Metallurgical Transactions A, 1992, vol. 23A, (3), pp. 903-918.

14. L. Shi and D.O. Northwood: "Recent Progress in the Modeling of High-Temperature Creep and Its Application to Alloy Development", J. of Materials Engineering and Performance, 1995, vol. 4, (2), pp. 196-211.

15. S.J. Zinkle: Report No. DOE/ER-0045/16, pp. 163-167, Progress Report, March 31, 1986.

16. J.E. Synk and K. Vedula: Mater. Sci. and Technology, 1987, vol. 3, pp. 72-75.

17. J.J. Stephen and D.T. Schmale: Sandia National Laboratories, Report No. SAND87-1296, , 1987.

18. J.J. Stephen, R.J. Bourcier, F.J. Vigil and D.T. Schmale: Sandia National Laboratories, Report No. SAND88-1351, 1988.

19. V.R. Barabash, G.L. Saksagansky, Y.F. Shevakin and e. al.: Report No. ITER-IL-NE-10-3, ITER Specialist Meeting on Materials Data Base, Feb. 1990.

20. T.J. Miller, S.J. Zinkle and B.A. Chin: J. Nucl. Mater., 1991, vol. 179-181, pp. 263-266.

21. H. Gravemann: "Materials for Mold Liners for Continuous Casting of Steel Present Position and Latest Trends.", Presented at the Duisburger StranggieBstage, London, England, 1984.

22. W. Vandermeulen, V. Massaut, J.V.d. Velde and W. Hendrix: Proc. 14 th Symp. on Fusion Technology, Pergamon Press, NY, 1986, pp. 1031-1035.

23. S.V. Raj and T.G. Langdon: "Creep Behavior of Copper at Intermediate Temperatures I. Mechanical Characteristics", Acta Metall., 1988, vol. 37, (3), pp. 843-852.

24. M.S. Nagorka, G.E. Lucas and C.G. Levi: "Novel Oxide-Dispersion-Strengthened Copper Alloys from Rapid Solidified Precursors: Part 2. Creep Behavior", Metallurgical and Materials Transactions A, 1995, vol. 26A, (April), pp. 873-881.

25. S.E. Broyles, K.R. Anderson, J.R. Groza and J.C. Gibeling: "Creep Deformation of Dispersion-Strengthened Copper Alloys from Rapid Solidified Precursors: Part 2. Creep Behavior", Metallurgical Transactions A, 1995, vol. 27, (May), pp. 1217-1227. 
26. A. Ayensu and T.G. Langdon: "The Inter-Relationship between Grain Boundary Sliding and Cavitation during Creep of Polcrystalline Copper", Metallurgical Transactions A, 1996, vol. 27A, (April), pp. 901-907.

27. M.A. Morris and J.C. Joye: "Effect of the particle distribution on the Mechanism Controlling Deformation of a Copper Alloy at Intermediate Temperature", Acta Mater., 1995, vol. 43, (1), pp. 69-81.

28. C. Dubois and M.A. Morris: "Influence of the Threshold Stress on the Creep Properties of a Cu-Cr-Zr Alloy Containing Dispersoid Particles", Scripta Metallurgia et Materialia, 1994, vol. 30, (7), pp. 827-832.

29. W.D. Nix and J.C. Gibeling: Flow and Fracture at Elevated Temperature, Amer. Soc. for Metals, Metals Park, 1985.

30. P.W. Taubenlat, W.E. Smith and A.R. Graviano: High Conductivity Copper and Aluminum Alloys, Metallurgical Society of AIME, Warrendale, 1984, pp. 19-29.

31. J. Robles, K.R. Anderson, J.R. Groza and J.C. Gibeling: "Low-Cycle Fatigue of Dispersion-Strengthened Copper", Metallurgical and Materials Transactions A, 1994, vol. 25A, (October), pp. 2235-2245.

32. T.S. Srivatsan, S. Anand and J.D. Troxell: "High Strain Cyclic Fatigue and Fracture of an Oxide Dispersion Strengthened Copper Alloy", Engineering Fracture Mechanics, 1993, vol. 46, (2), pp. 183-198.

33. K. Hibbitt, \& Sorensen, Inc.,: "ABAQUS User's Manual", Providence, RI, 1997.

34. O.C. Zienkiewicz: The Finite Element Method, Third Edition ed., McGraw-Hill Book Company (UK) Limited, Now York, 1984.

35. S. Suresh: Fatigue of Materials, Cambridge University Press, Cambridge, 1991, pp. 617.

36. S.S. Manson: Behavior of Materials under Conditions of Thermal Stress, National Advisory Commission on Aeronautics, Report No. 1170, Cleveland: Lewis Flight Propulsion Laboratory.

37. S.S. Manson and G.R. Halford: Int. J. Fracture, 1981, vol. 17, pp. 169.

38. L.F. Coffin: "A study of the effects of cyclic thermal stresses on a ductile metal", Transactions of ASME, 1954, vol. 76, pp. 931-50.

39. H. Sehitoglu: "Thermal-Mechanical Fatigue Life Prediction Methods", ASTM STP, 1990, vol. 1122, pp. 47-77. 
40. J.F. Stubbins, P. Kurath, D. Drockelman, G.D. Morgan, J. McAfee, G. Li and B.G. Thomas: "Analysis of Copper Alloy to Stainless Steel Bonded Panels for ITER First Wall Applications", 1995 16th IEEE/NPSS Symposium on Fusion Engineering, University of Illinois at Urbana-Champaign, IL, USA, 1995, pp. 174-177.

41. K.D. Leedy and J.F. Stubbins: Private communication, University of Illinois at UrbanaChampaign, Urbana, IL, June, 1996.

42. B.E. Jelke: Low Cycle Fatigue and Crack Growth in Oxygen Free High Conductivity Copper, Master of Sci. Thesis, University of Illinois at Urbana-Champaign, 1989.

43. K. Hatanaka and Y. Ishimoto: "An Analysis of Strain Rate Dependent Cyclic StressStrain Response and Fatigue Life in Copper", Proc. of the 1992 Joint ASME/JSME Conference on Electronic Packaging, Milpitas, CA, USA, ASME, 1992, pp. 813-818.

44. M.C. Billone: Summary of Recommended Correlations for Annealed Type 316 LN Stainless Steel for the ITER Material Properties Handbook, Argonne National Laboratory, Report No. DOE/ER-0313/19, p295, Fusion Reactor Material Semiannual Progress Report, Dec. 31, 1995.

45. G. Li: Analysis of Thermal and mechanical Behavior of High Heat Flux Facing Copper Walls, Ph. D. Thesis, University of Illinois at Urbana-Champaign, 1996.

\section{LIST OF FIGURES}

Figure 1 (a) - Strength and thermal conductivity of copper alloys (at $\left.20^{\circ} \mathrm{C}\right)^{[5]}$

Figure 1 (b) - Strength $\left(\right.$ at $300^{\circ} \mathrm{C}$ ) and thermal conductivity (at $20^{\circ} \mathrm{C}$ ) of copper alloys [12]

Figure 2 - Temperature effect on the yield strength of $\mathrm{Cu}-\mathrm{Al}_{2} \mathrm{O}_{3} \cdot{ }^{[15-20]}$ (31 - 80\% Cold Work)

Figure 3 - Temperature effect on the yield strength of $\mathrm{Cu}-\mathrm{Cr}-\mathrm{Zr}$ alloys $[5,21]$

Figure 4 - Steady-state thermal creep laws for copper alloys [11, 14, 23-30]

Figure 5 - Creep strain from test data and creep laws for $\mathrm{Cu}-\mathrm{Ni}-\mathrm{Be}, \mathrm{Cu}-\mathrm{Cr}-\mathrm{Zr}$, and $\mathrm{Cu}-\mathrm{Ag}-\mathrm{P}[1,3]$

Figure 6 - Cyclic stress-strain curves of copper alloys at ambient temperature[36, 38]

Figure 7(a) - Fatigue lifetime of copper alloys, based on total strain amplitude [3, 6, 8, 42]

Figure 7(b) - Fatigue lifetime of copper alloys, based on plastic strain amplitude [31, 32, 42, 43]

Figure 8(a) - Temperature effect on the fatigue lifetime of $\mathrm{Cu}-\mathrm{Ni}-\mathrm{Be}$ [41]

Figure 8(b) - Temperature effect on the fatigue lifetime of $\mathrm{Cu}-\mathrm{Cr}-\mathrm{Zr}$ [41]

Figure 8(c) -- Temperature effect on the fatigue lifetime of $\mathrm{Cu}-\mathrm{Al}_{2} \mathrm{O}_{3}$ [41] 
Figure 9 - Experimental specimen and four-point load conditions for bending fatigue tests Figure 10 - Stress distribution along centerline of bending fatigue test specimen A-14 at maximum load predicted by elastic-plastic finite-element model and elastic analytical solution $\left(250^{\circ} \mathrm{C}\right)$

Figure 11 - Elastic-plastic-creep model predictions of $\mathrm{x}$-stress and plastic strain distributions at maximum load (Specimen A-14)

Figure 12 - Elastic-plastic-creep model prediction of raw fatigue-test measurements at early cycles (Specimen A-14 at $250^{\circ} \mathrm{C}$ )

Figure 13 a) - Elastic-plastic-creep model prediction of raw fatigue-test measurements at long cycles (Specimen A-14 at $250^{\circ} \mathrm{C}$ )

Figure 13 b) - Elastic-plastic-creep model prediction of raw fatigue-test measurements at long cycles (Specimen A-13 at $250^{\circ} \mathrm{C}$ )

Figure 14(a) - Copper alloy creep laws compared with A-14 test data (Maximum load $=13 \mathrm{kN}$, $\left.\mathrm{T}=250^{\circ} \mathrm{C}\right)$

Figure 14(b) - Copper alloy creep laws compared with A-12 test data (Maximum load $=9.5 \mathrm{kN}$, $\left.\mathrm{T}=250^{\circ} \mathrm{C}\right)$

\section{LIST OF TABLES}

Table I - Copper Alloys for High-strength, High Heat Flux Applications

Table II - Creep Strain Experimental Data for Copper Alloys

Table III - Fatigue Test Measurements

Table IV - Material properties 


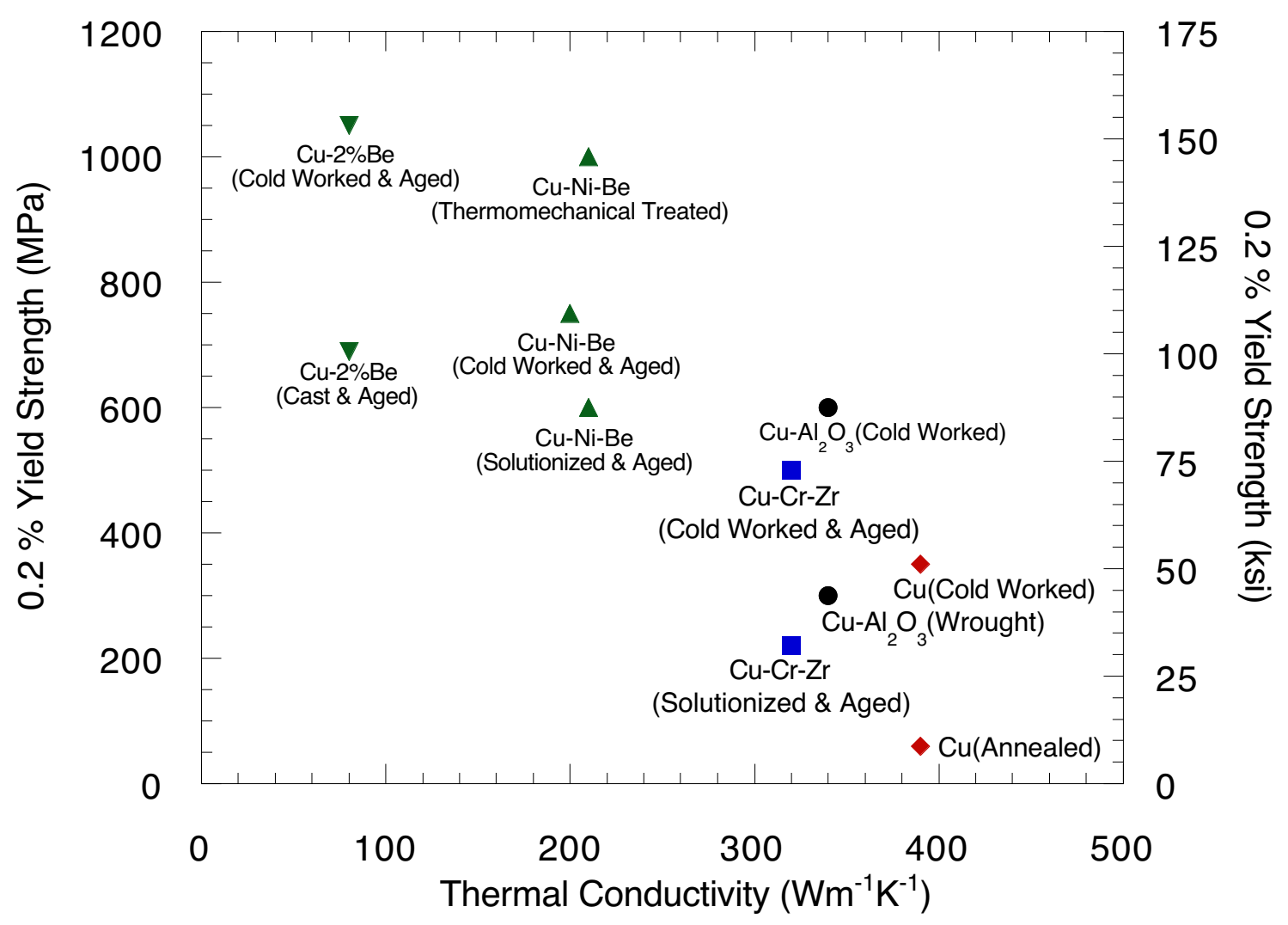

Figure 1(a) - Strength and thermal conductivity of copper alloys (at $\left.20^{\circ} \mathrm{C}\right)^{[5]}$ 


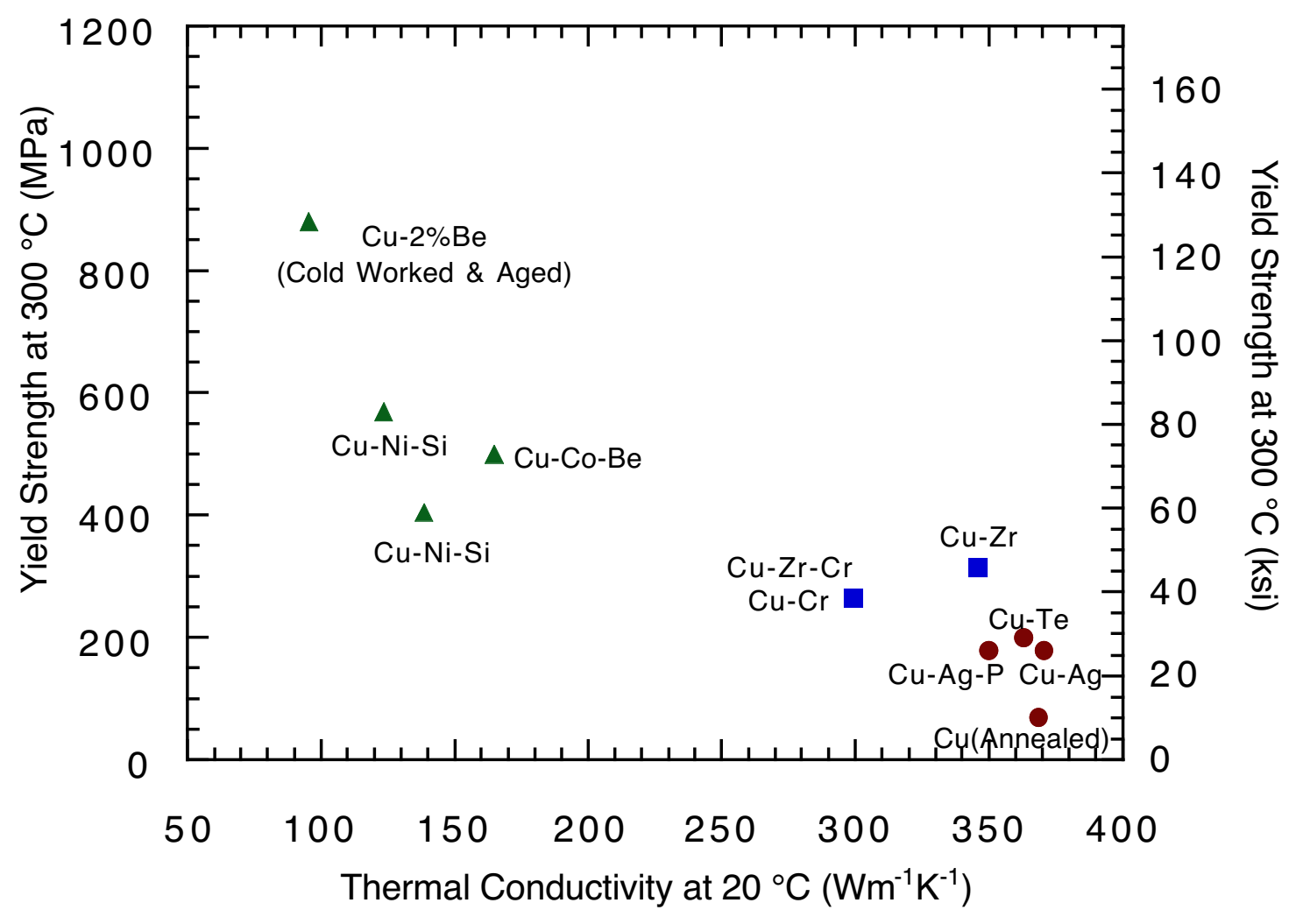

Figure 1(b) - Strength (at $300{ }^{\circ} \mathrm{C}$ ) and thermal conductivity (at $20^{\circ} \mathrm{C}$ ) of copper alloys[12] 


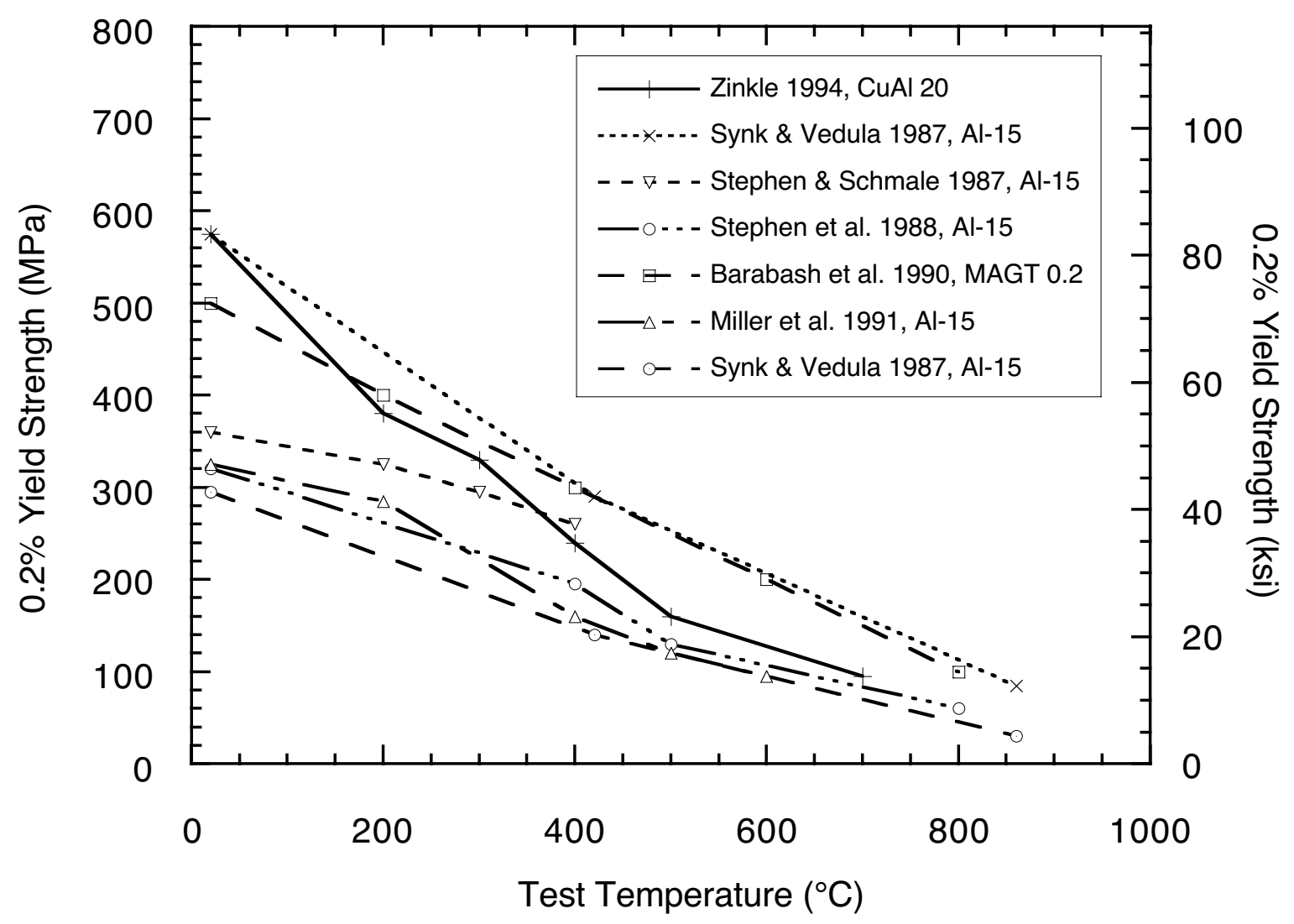

Figure 2 - Temperature effect on the yield strength of $\mathrm{Cu}-\mathrm{Al}_{2} \mathrm{O}_{3}{ }^{[15-20]}(31-80 \%$ Cold Work) 


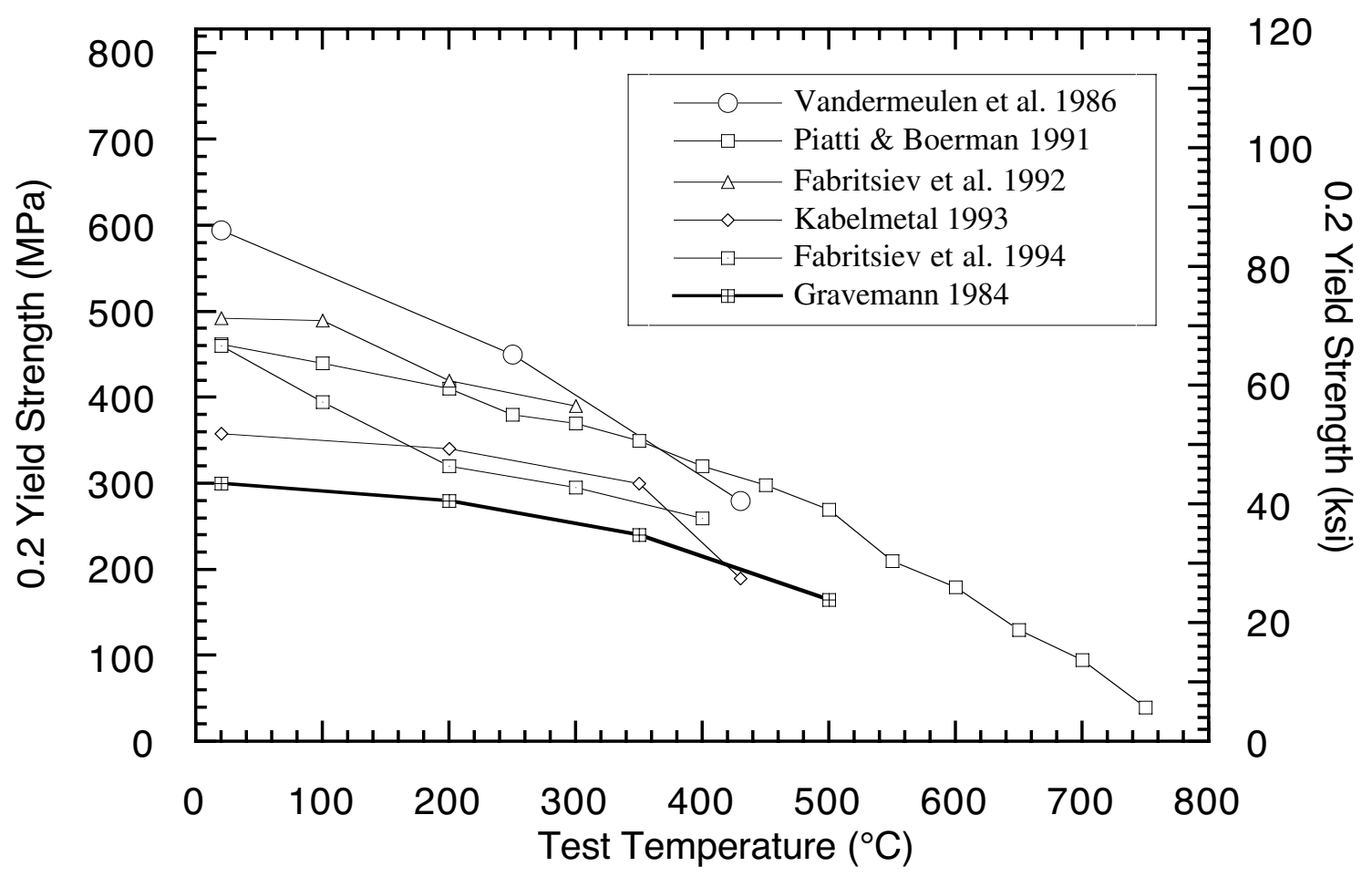

Figure 3 - Temperature effect on the yield strength of $\mathrm{Cu}-\mathrm{Cr}-\mathrm{Zr}$ alloys $[5,21]$ 


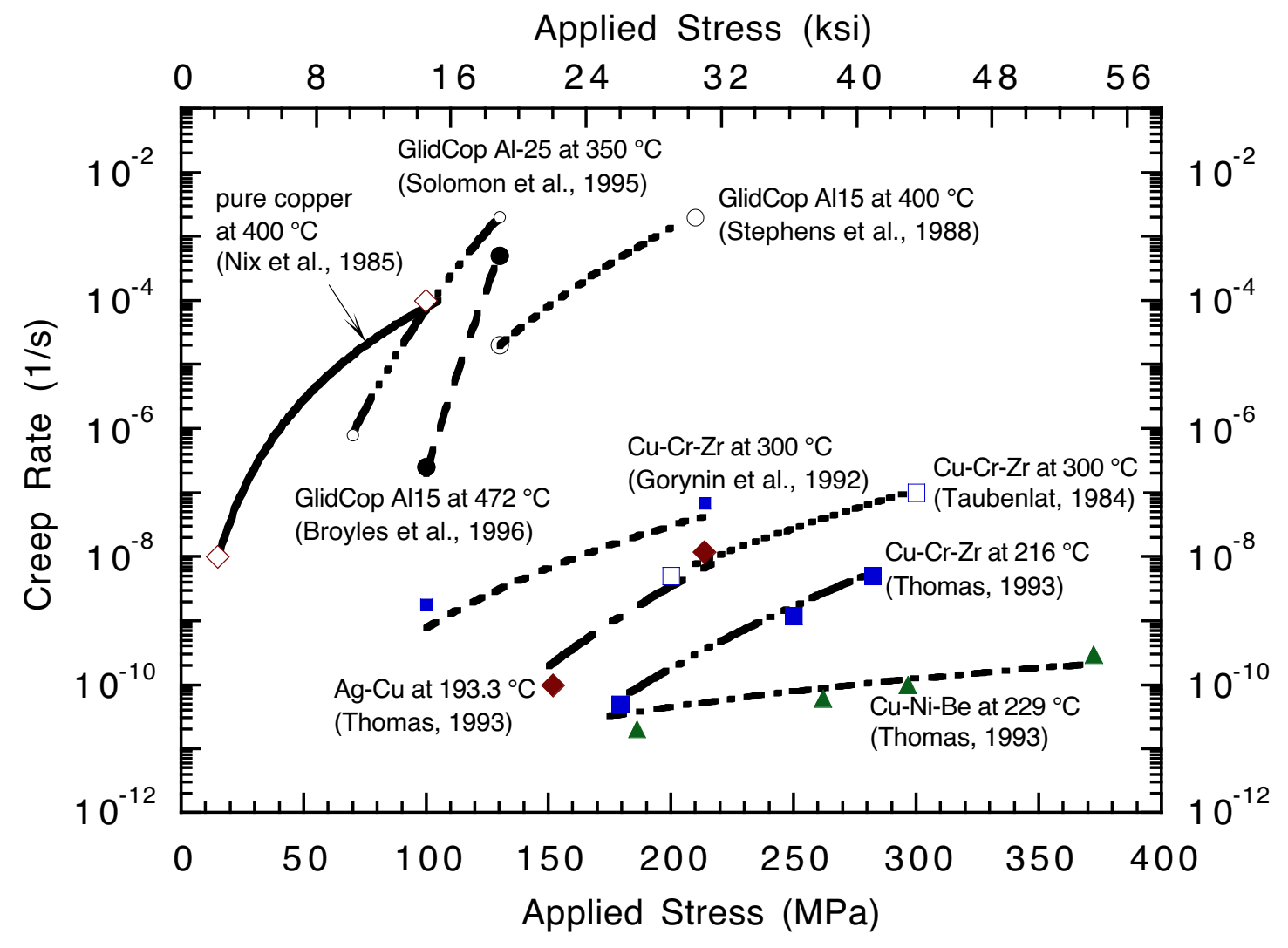

Figure 4 - Steady-state thermal creep laws for copper alloys [11, 14, 23-30] 


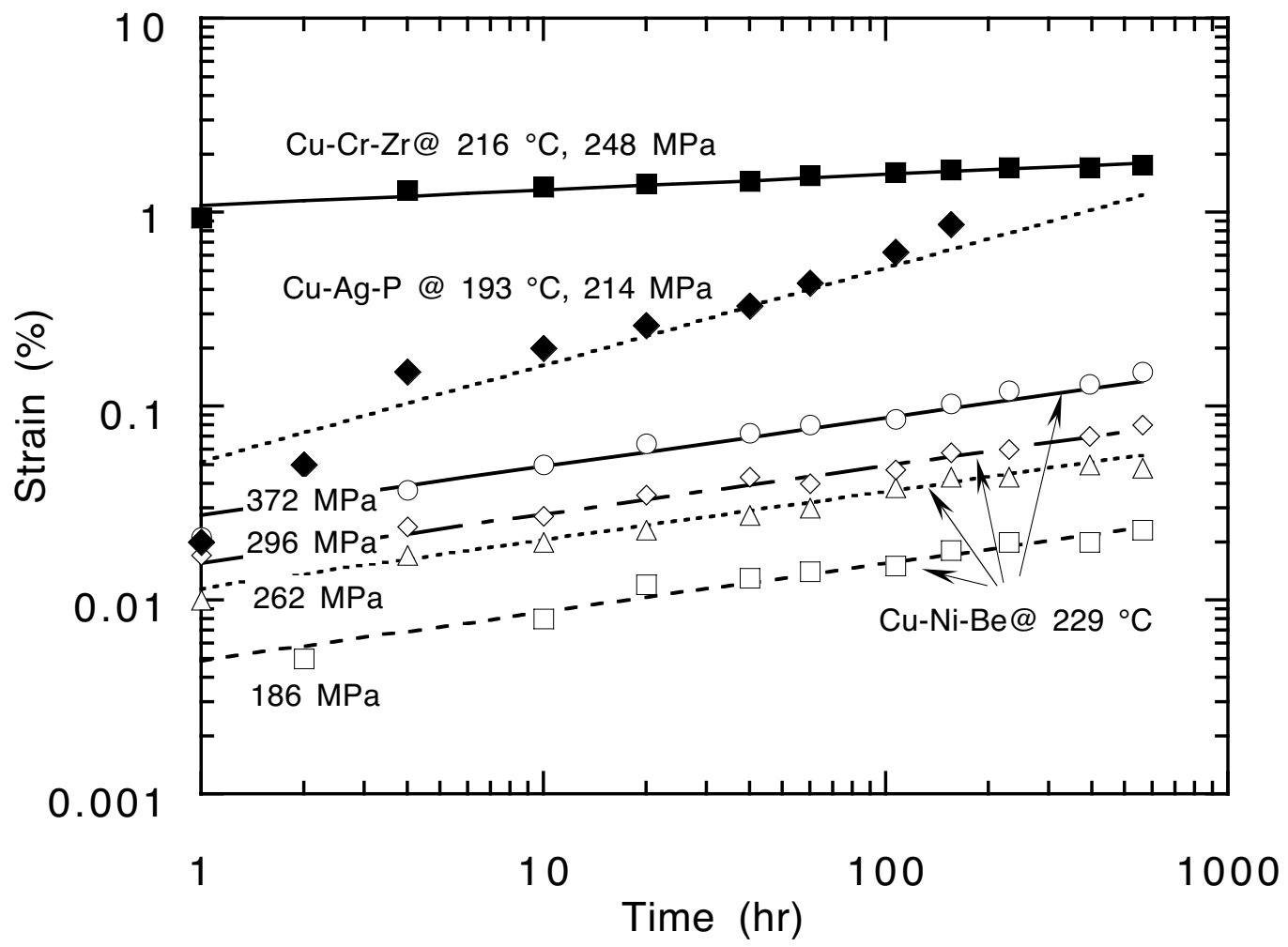

Figure 5 - Creep strain from test data and creep laws for $\mathrm{Cu}-\mathrm{Ni}-\mathrm{Be}, \mathrm{Cu}-\mathrm{P}-\mathrm{Ag}$, and $\mathrm{Cu}-\mathrm{Cr}-\mathrm{Zr}[1,3]$ 


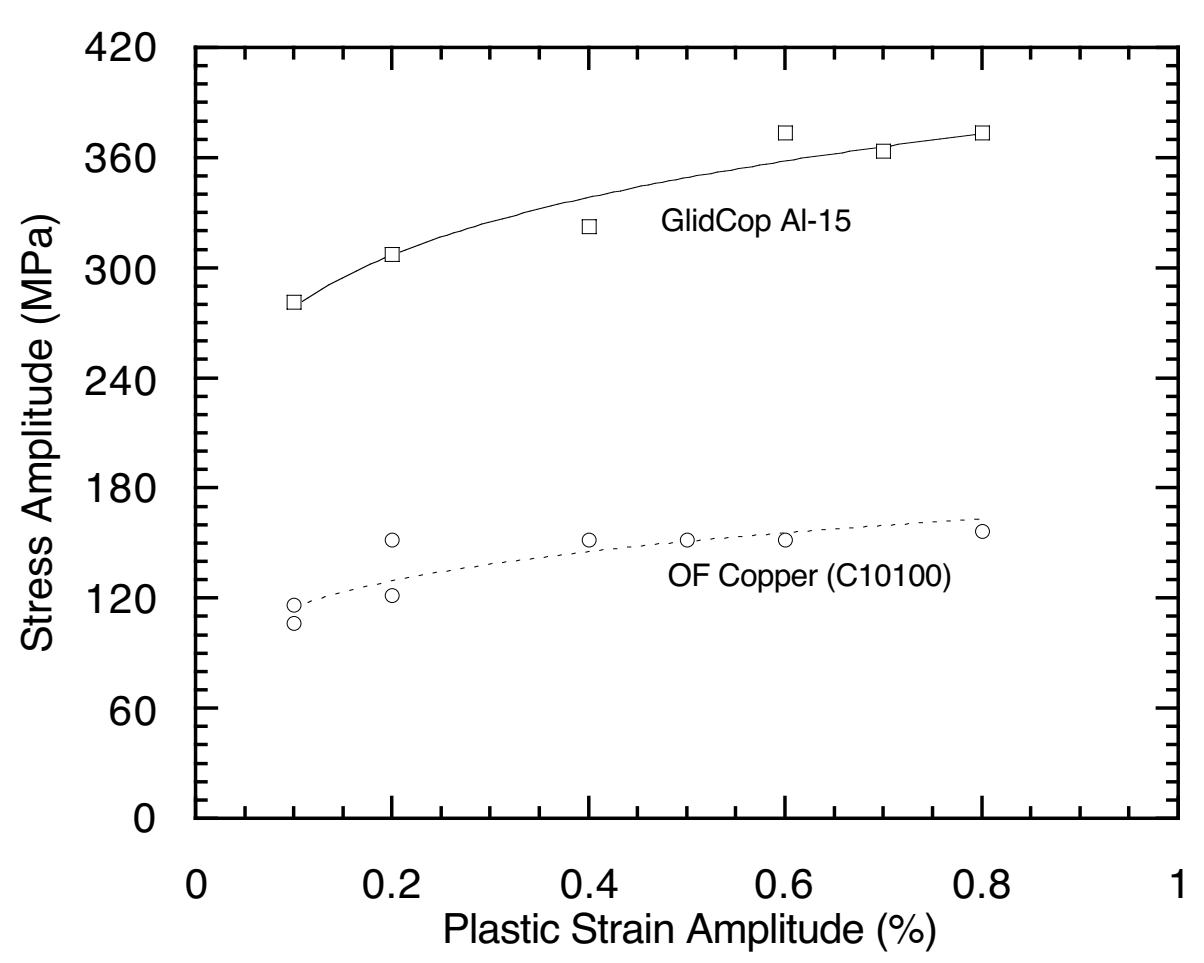

Figure 6 - Cyclic stress-strain curves of copper alloys at ambient temperature[36, 38]

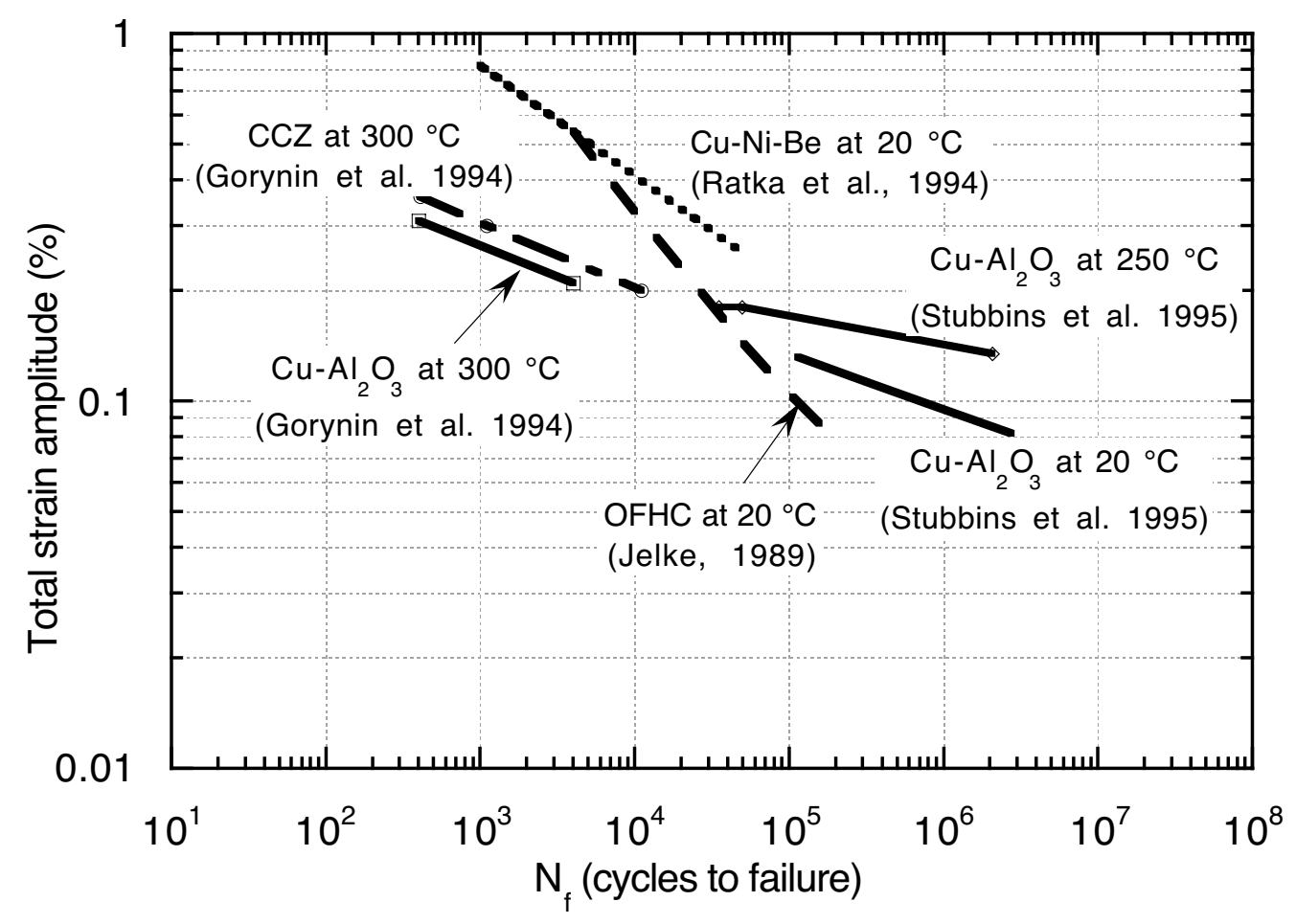

Figure 7(a) - Fatigue lifetime of copper alloys, based on total strain amplitude $[3,6,8,42]$ 


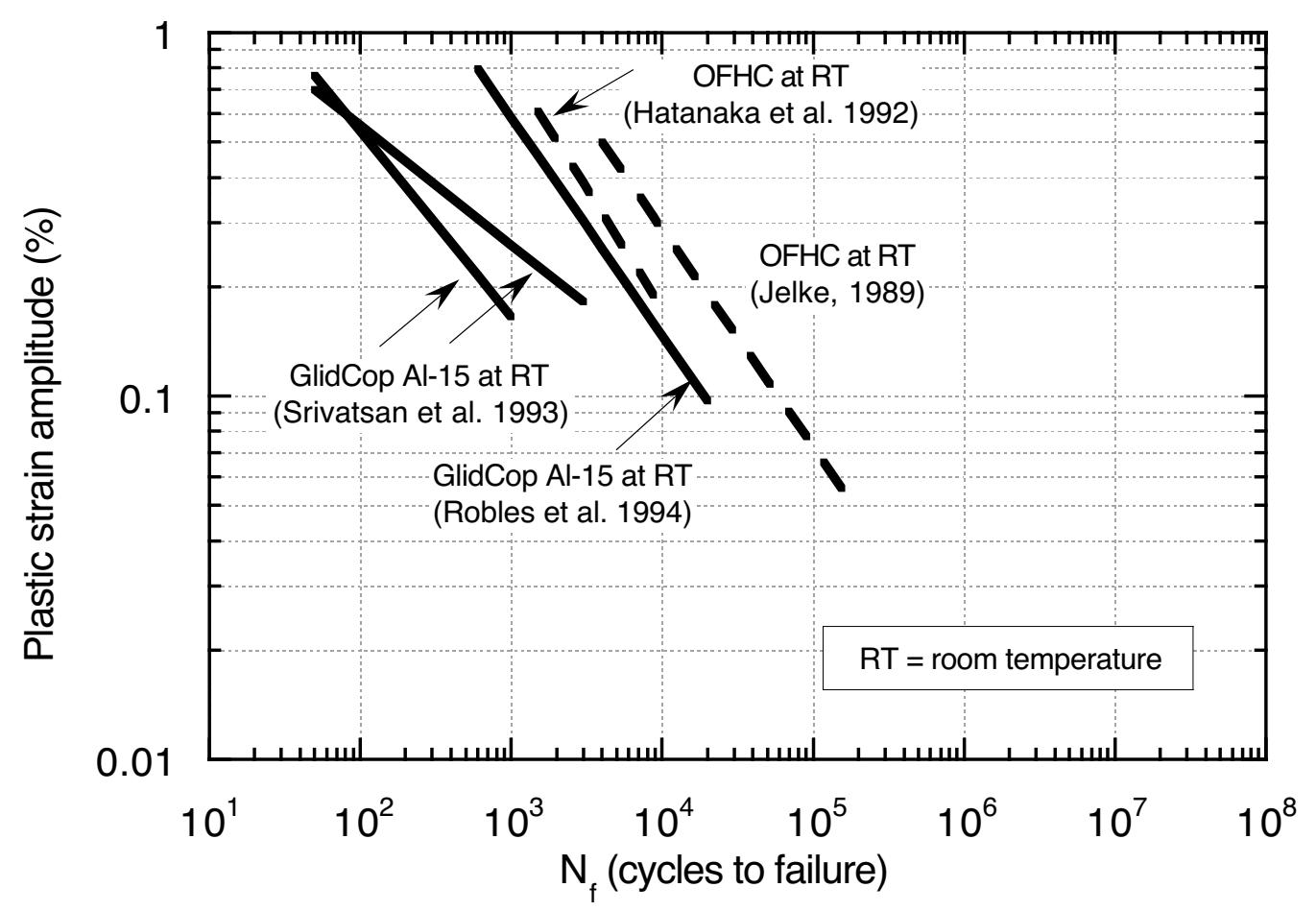

Figure 7(b) - Fatigue lifetime of copper alloys, based on plastic strain amplitude[31, 32, 42, 43]

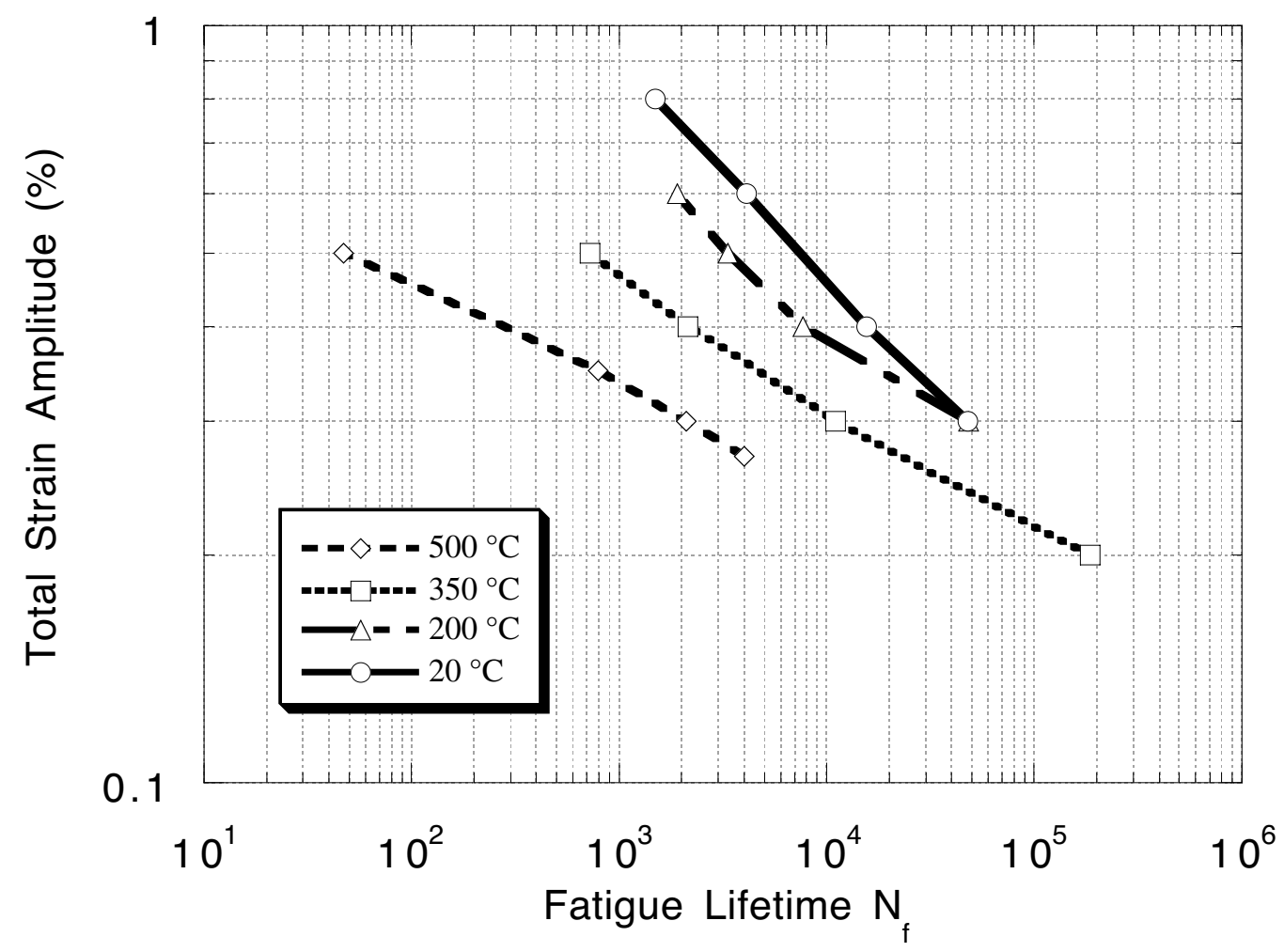

Figure $8(a)$ - Temperature effect on the fatigue lifetime of $\mathrm{Cu}-\mathrm{Ni}-\mathrm{Be}^{[41]}$ 


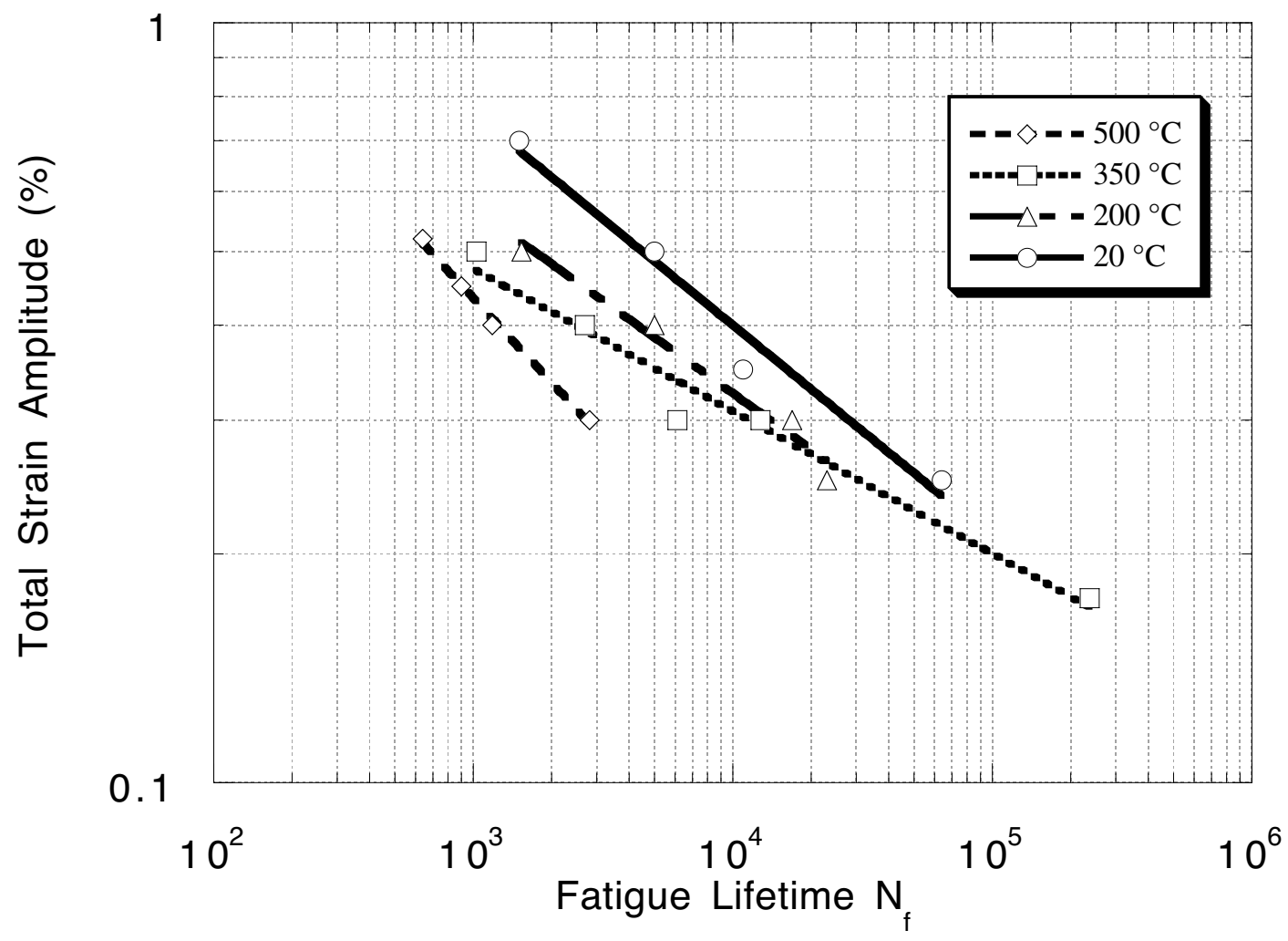

Figure $8(b)$ - Temperature effect on the fatigue lifetime of $\mathrm{Cu}-\mathrm{Cr}-\mathrm{Zr}[41]$

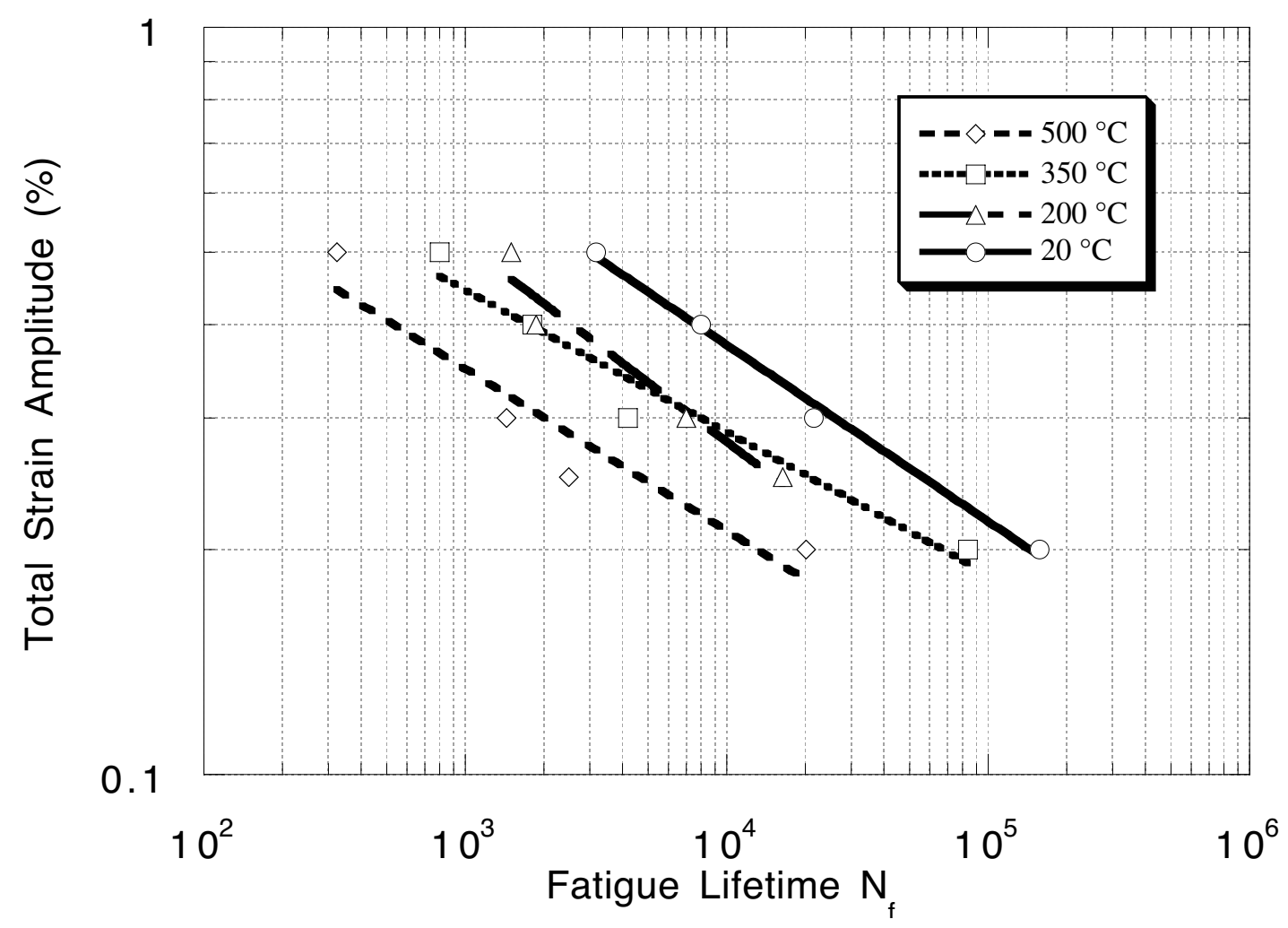

Figure 8(c) - Temperature effect on the fatigue lifetime of $\mathrm{Cu}-\mathrm{Al}_{2} \mathrm{O}_{3}[41]$ 


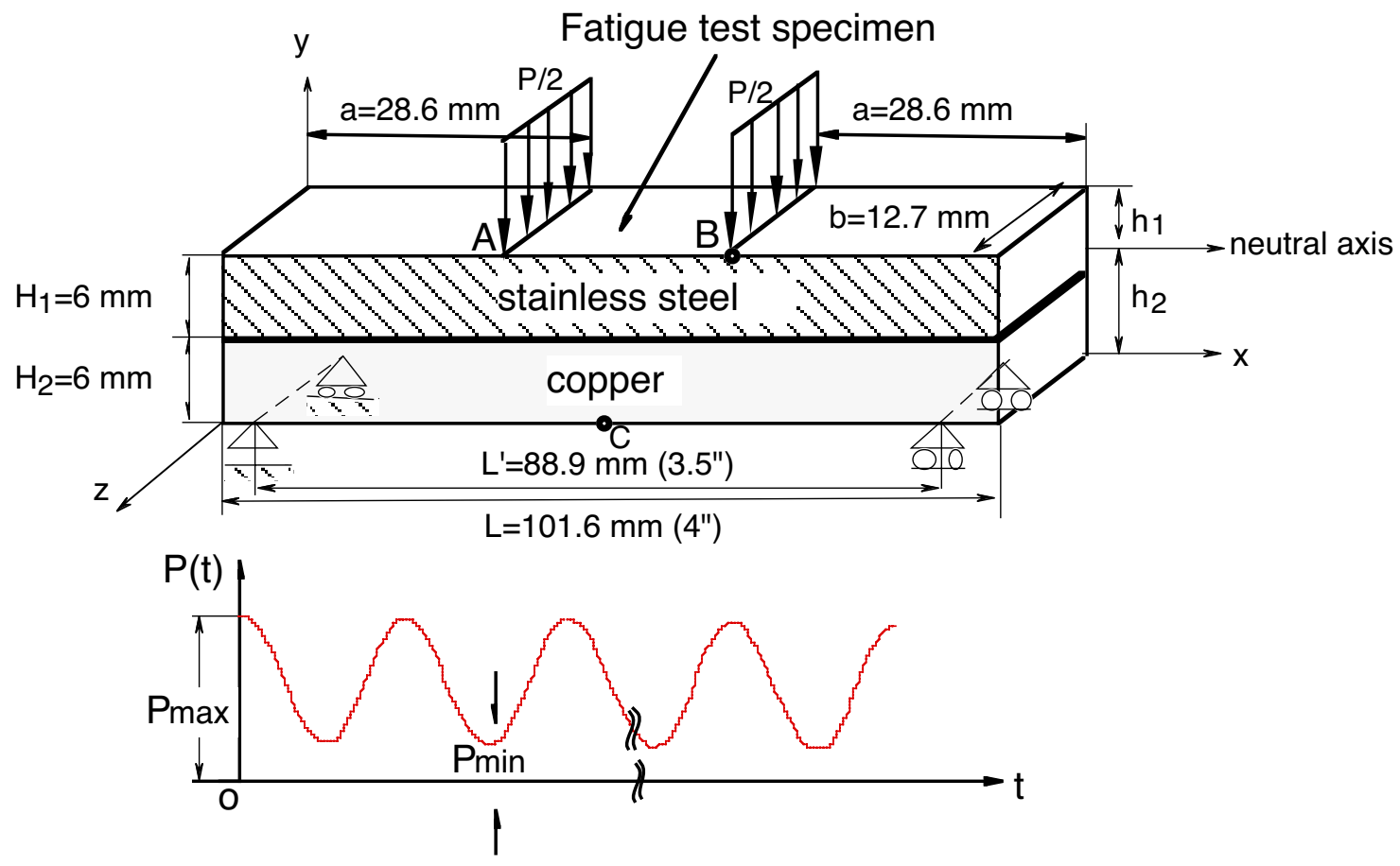

Figure 9 - Experimental specimen and four-point load conditions for bending fatigue tests 


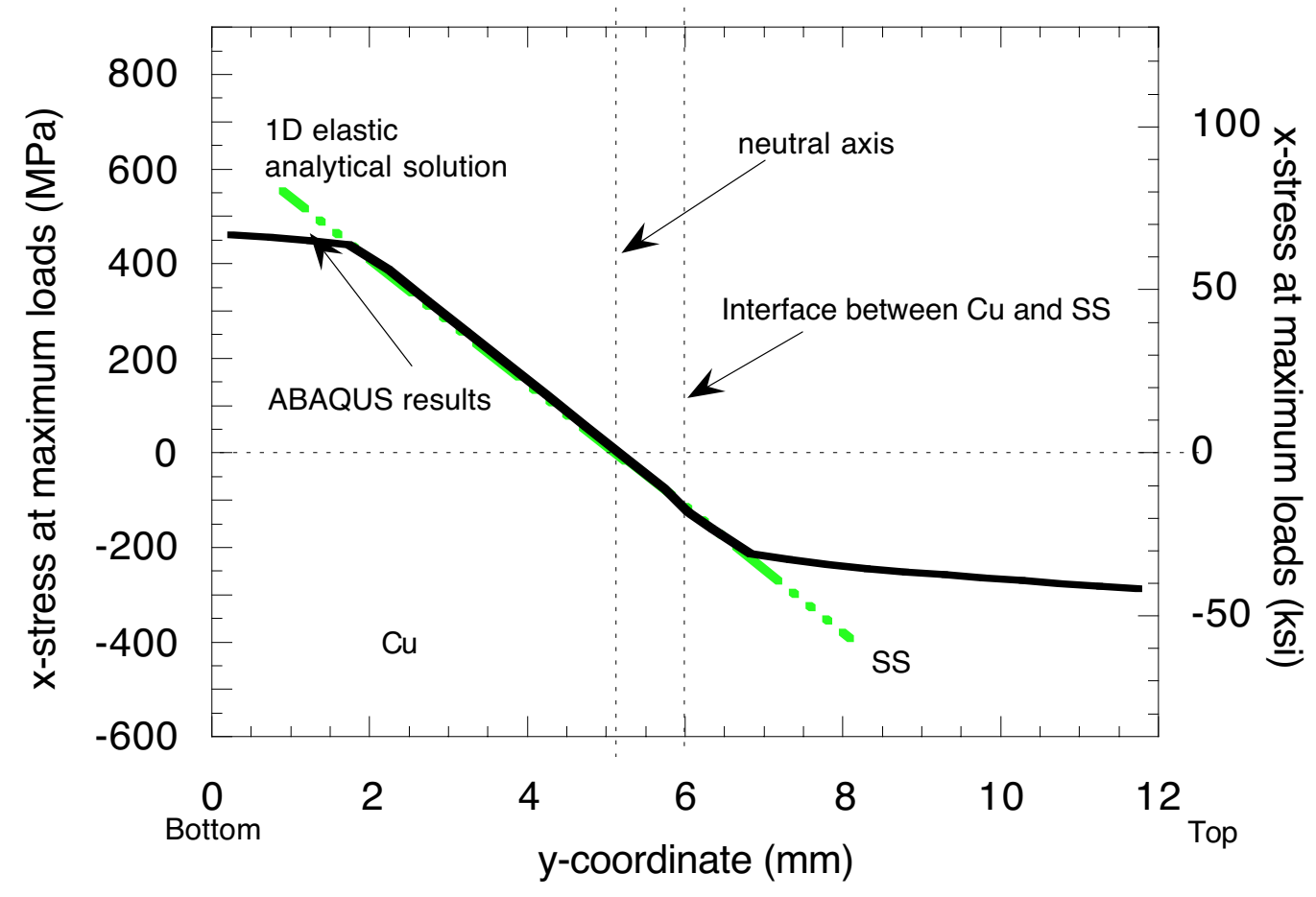

Figure 10 - Stress distribution along centerline of bending fatigue test specimen A-14 at maximum load predicted by elastic-plastic finite-element model and elastic analytical solution $\left(250{ }^{\circ} \mathrm{C}\right)$ 

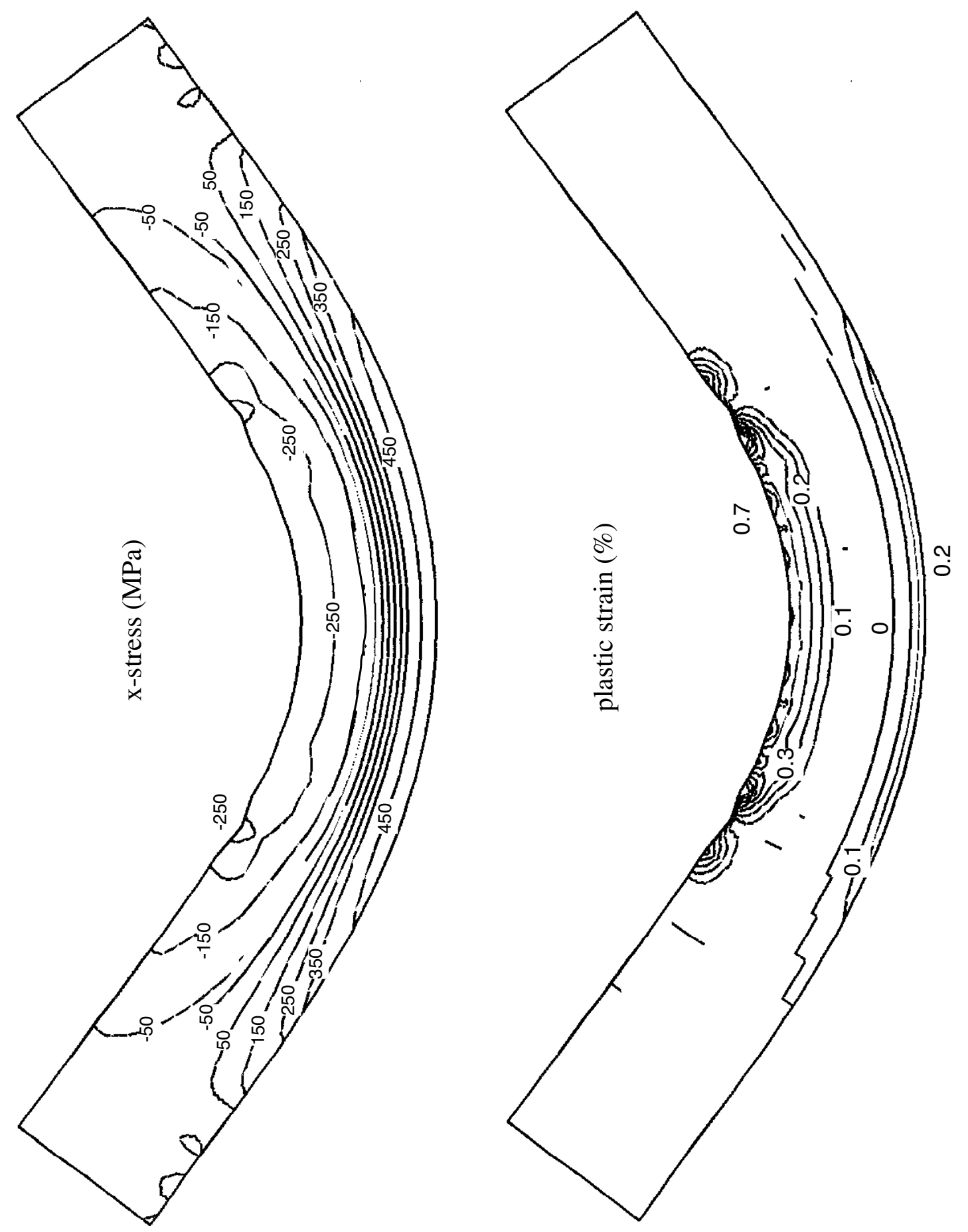

Figure 11 - Elastic-plastic-creep model predictions of x-stress and plastic strain distributions at maximum load (Specimen A-14) (1:20) 


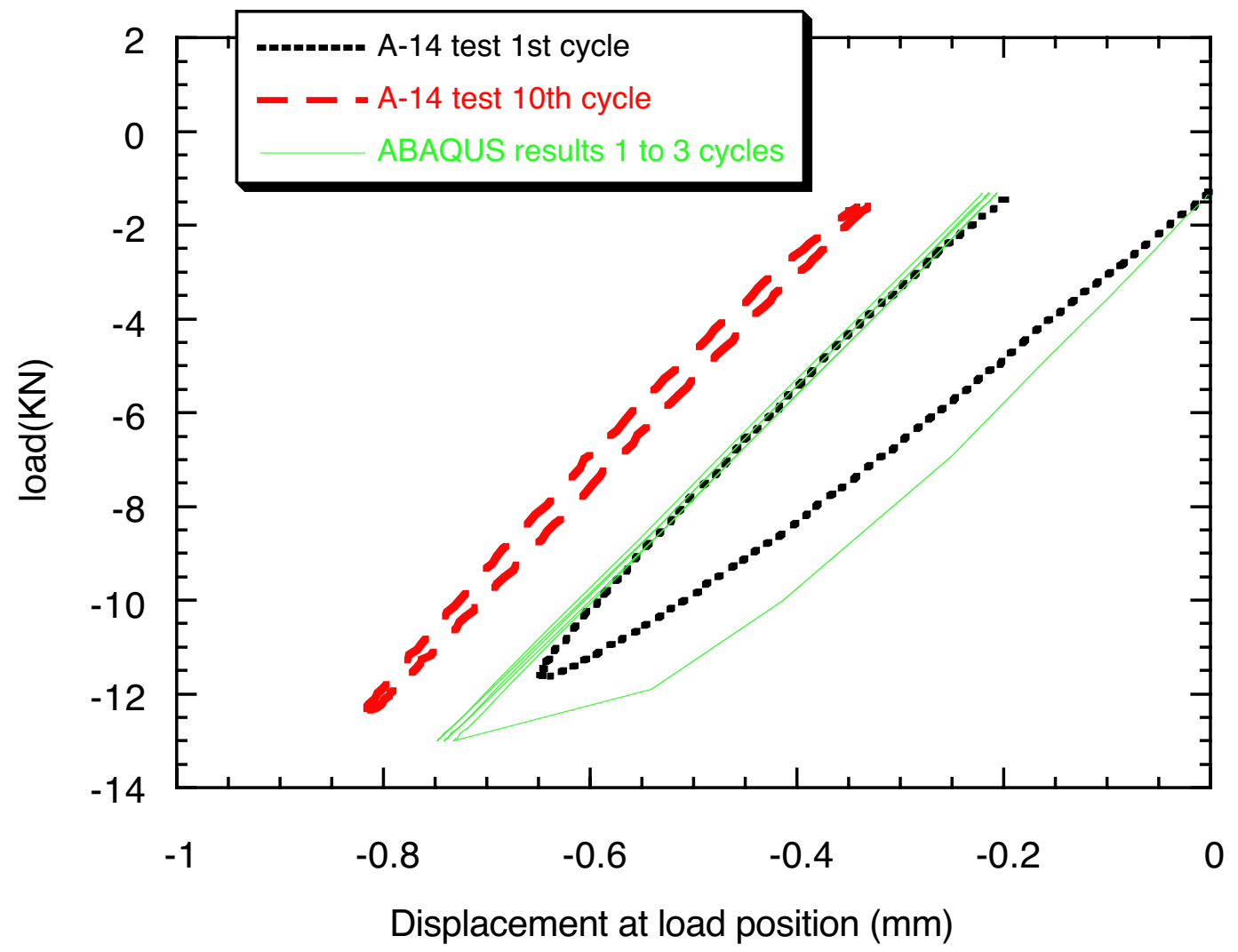

Figure 12 - Elastic-plastic-creep model prediction of raw fatigue-test measurements at early cycles (Specimen A-14 at $250^{\circ} \mathrm{C}$ ) 


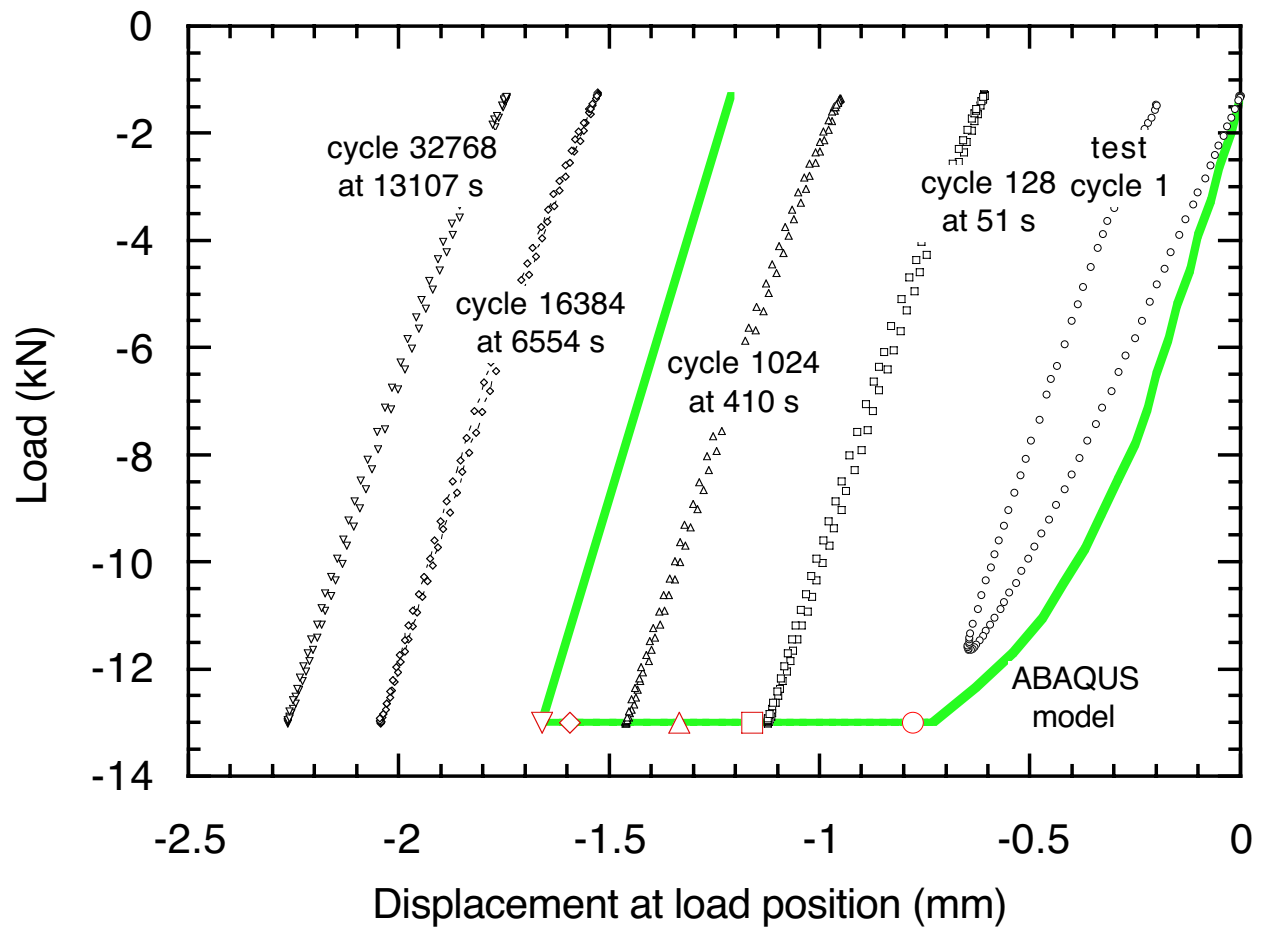

Figure 13(a) - Elastic-plastic-creep model prediction of raw fatigue-test measurements at long cycles (Specimen A-14 at $250^{\circ} \mathrm{C}$ ) 


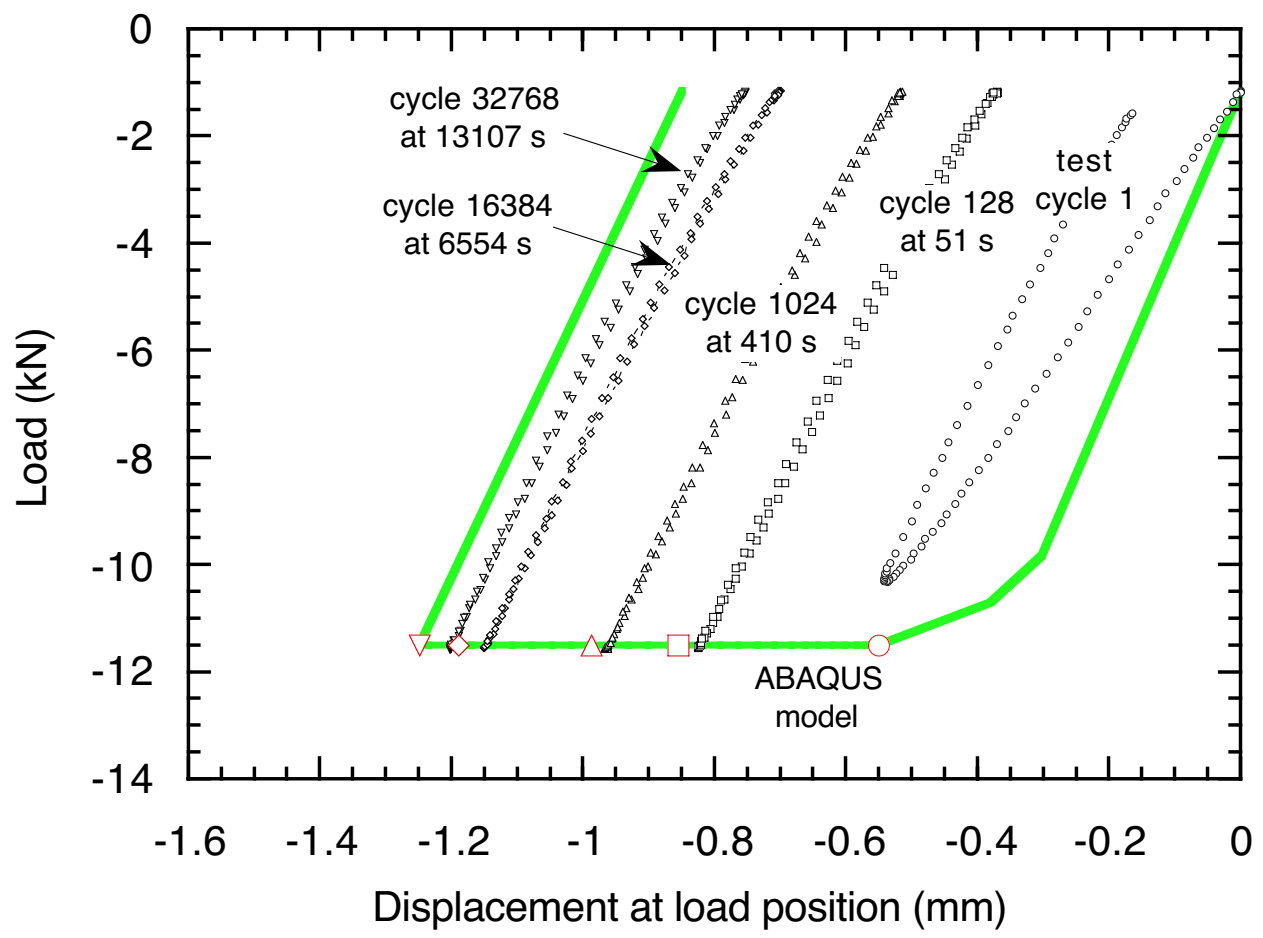

Figure 13(b) - Elastic-plastic-creep model prediction of raw fatigue-test measurements at long cycles (Specimen A-13 at $250{ }^{\circ} \mathrm{C}$ ) 


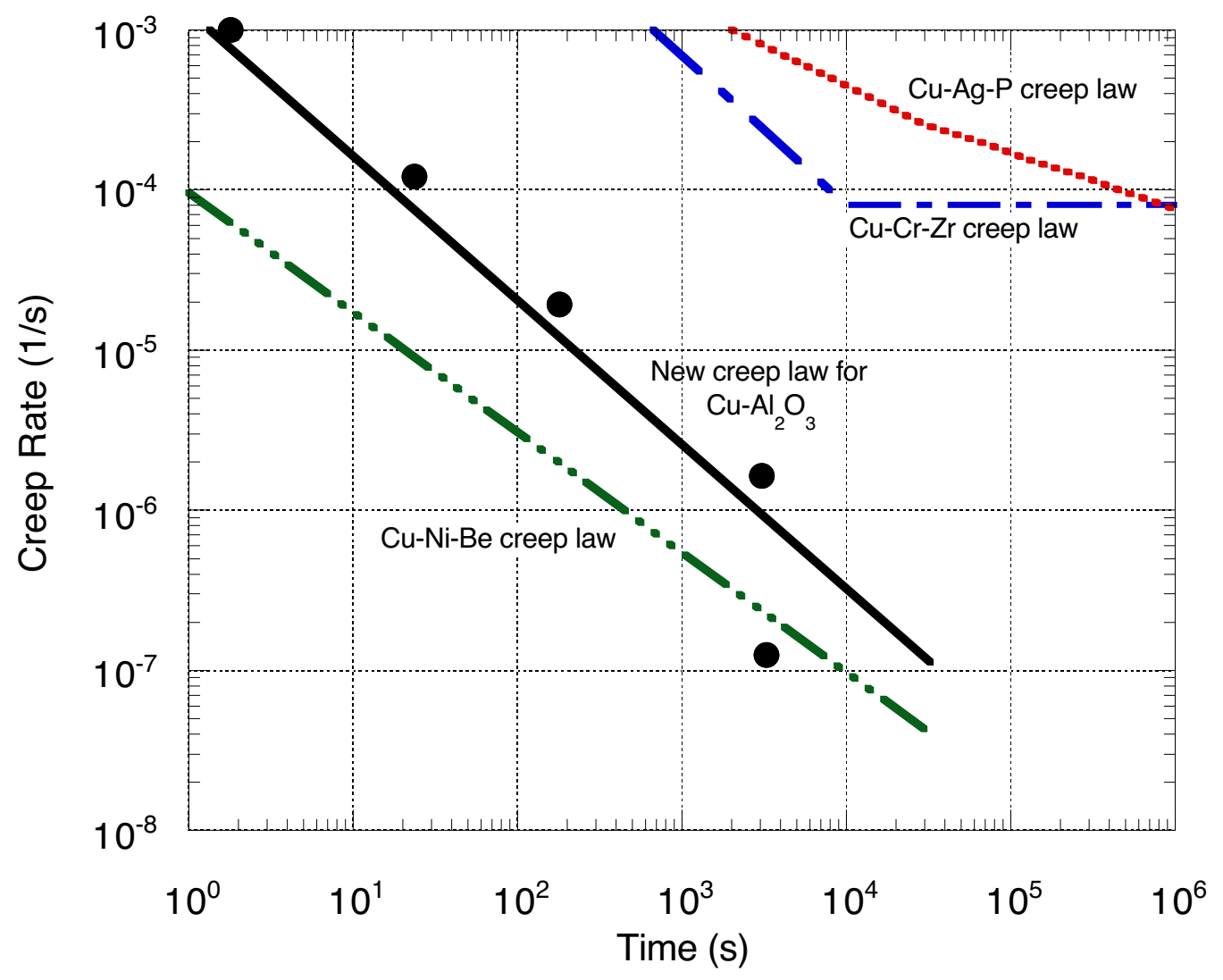

Figure 14(a) - Copper alloy creep laws compared with A-14 test data (Maximum load $=13 \mathrm{kN}, \mathrm{T}=250{ }^{\circ} \mathrm{C}$ ) 


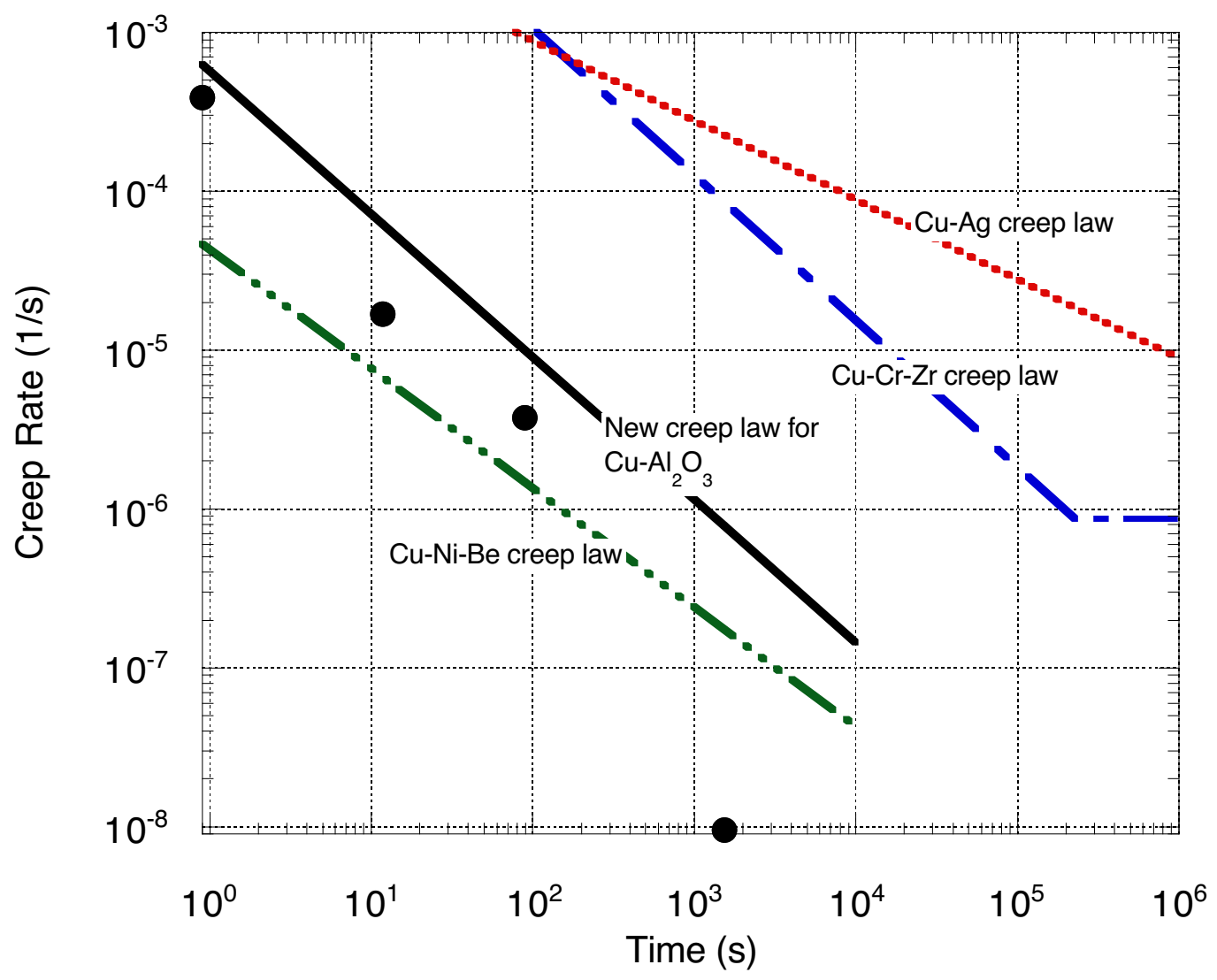

Figure 14(b) - Copper alloy creep laws compared with A-12 test data $\left(\right.$ Maximum load $=9.5 \mathrm{kN}, \mathrm{T}=250^{\circ} \mathrm{C}$ ) 